\title{
EFFECTS OF A COMMERCIAL FEED ADDITIVE ON PRODUCTION LOSSES DURING ACUTE HEAT STRESS CONDITIONS IN MID-LACTATION HOLSTEIN DAIRY COWS
}

\author{
A Thesis \\ Presented to
}

the Faculty of the Graduate School

at the University of Missouri

\author{
In Partial Fulfillment \\ of the Requirements for the Degree \\ Master of Science
}

by

KERRIE DAVISON

Dr. Matthew Waldron, Thesis Supervisor

December 2013 
The undersigned, appointed by the Dean of the Graduate School, have examined the thesis entitled:

\section{EFFECTS OF A COMMERCIAL FEED ADDITIVE ON PRODUCTION LOSSES DURING ACUTE HEAT STRESS CONDITIONS IN MID-LACTATION HOLSTEIN DAIRY COWS}

presented by Kerrie Davison, a candidate for the degree of Master of Science and hereby certify that, in their opinion, it is worthy of acceptance.

Dr. Matthew Waldron, PhD

Dr. Monty Kerley, PhD

Dr. Scott Poock, DVM 


\section{ACKNOWLEDGMENTS}

I would like to thank my research and thesis advisor, Dr. Matthew Waldron for his support and guidance with my thesis project. I would also like to thank my committee members, Dr. Monty Kerley and Dr. Scott Poock for serving on my thesis committee and for assisting with the writing process. Furthermore, I wish to thank Nicole Barkley, Ann Kenny, and Ricardo Rodrigues for all of their help in planning and orchestrating my animal trial, your support proved invaluable. Additionally, I would like to thank John Denbigh and Eric Adkins for their help with my animal trial and for their willingness to assist me in my research. I would also like to thank Stephen Repking, Clinton Eastburn, Adam Birk, Alex Keene and all the other undergradutate students working in our lab for their help with my project. I would especially like to thank Land O' Lakes Purina for providing the funding for my project and for their advice and guidance throughout this endeavor. Finally, I would like to thank my family and friends for all of their support and encouragement during this process. I would like to personally thank my Uncle Andrew for all of his help in editing my thesis, Mary Smith for her formatting advice, and Corey Lange for his technical and formatting assistance. 


\section{TABLE OF CONTENTS}

ACKNOWLEDGMENTS ................ ii

LIST OF TABLES $\ldots \ldots \ldots \ldots \ldots \ldots \ldots \ldots$

LIST OF FIGURES $\ldots \ldots \ldots \ldots \ldots \ldots$ vi

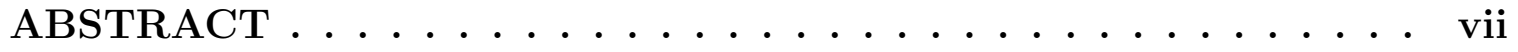

\section{CHAPTER}

1 Literature Review . . . . . . . . . . . . . . 1

1.1 Introduction . . . . . . . . . . . . . . . . . 1

1.2 Defining Heat Stress . . . . . . . . . . . . . . . . 2

1.2.1 Physiological Response to Heat Stress . . . . . . . . . . . . 2

1.2.2 Ambient Temperatures vs. Temperature Humidity Index . . . 5

1.3 Effects of Heat Stress on Production $\ldots \ldots \ldots \ldots \ldots$

1.3.1 Effects on Reproduction . . . . . . . . . . . . . . 7

1.3.2 Effects on Milk Production and Quality . . . . . . . . . . 9

1.3.3 Genetics and Response to Heat Stress . . . . . . . . . . . 11

1.4 Impact of Climate Change on Dairy Production . . . . . . . . . 14

1.5 Energy Balance . . . . . . . . . . . . . . . . . 15

1.5.1 Effects of Heat Stress on Energy Balance . . . . . . . . . 16

1.5.2 Metabolites and Lactation-induced NEBAL . . . . . . . . 19

1.5.3 Metabolites During Heat Stress Induced NEBAL _. . . . . 21 
1.6 Nutritional Strategies . . . . . . . . . . . . . . . . . . . . . . 22

1.7 Tables for Chapter $1 \ldots \ldots \ldots \ldots \ldots$

1.8 Figures for Chapter $1 \ldots \ldots \ldots \ldots \ldots \ldots \ldots$

2 Investigating the effects of a commercial feed additive on production losses during heat stress in mid-lactation Holstein cattle . . . 32

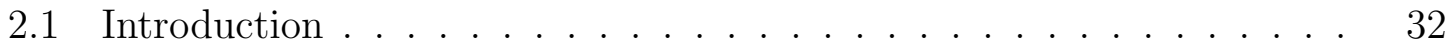

2.2 Materials and Methods . . . . . . . . . . . . . . . . . 34

2.2 .1 Calculations . . . . . . . . . . . . . . . . 36

$2.2 .2 \quad$ Statistical Analysis . . . . . . . . . . . . . . . . 37

2.3 Results and Discussion . . . . . . . . . . . . . . . 37

2.4 Conclusion . . . . . . . . . . . . . . . . . . . . . . . . . . . . 41

2.5 Acknowledgments . . . . . . . . . . . . . . . . . . 42

2.6 Tables for Chapter $2 \ldots \ldots \ldots \ldots$

2.7 Figures for Chapter $2 \ldots \ldots \ldots \ldots \ldots$

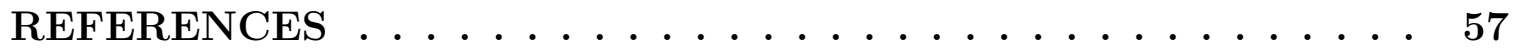
APPENDIX

A Supplementary Information for Chapter $2 \ldots \ldots \ldots 4$

A.1 Interpretive Summary . . . . . . . . . . . . . 64

A.2 Running Head $\ldots \ldots \ldots \ldots \ldots \ldots \ldots \ldots \ldots \ldots \ldots \ldots \ldots$ 


\section{LIST OF TABLES}

Table

Page

1.1 Linear trend in global and hemispheric temperature changes . . . . 26

2.1 Ingredients and chemical composition of the diet . . . . . . . . . . 43

2.2 Composition of the vitamins and minerals mix . . . . . . . . . . . . 45

2.3 Effects of RAL treatment on production variables, plasma metabolites, and body temperature during $\mathrm{P} 2 \ldots \ldots$. . . . . . . . . . 46

2.4 Production variables, plasma metabolites, and body temperature dur-

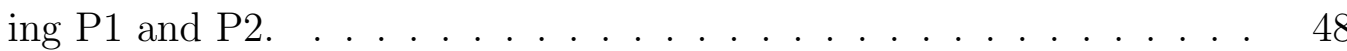




\section{LIST OF FIGURES}

Figure $\quad$ Page

1.1 Core body temperature in relation to environmental temperature . . 27

1.2 Thermal stress zones . . . . . . . . . . . . . . . . . . . . . 28

1.3 Comparison of average global and hemispheric temperatures . . . . . 29

1.4 Whole-body glucose demand during the periparturient period . . . . 30

1.5 Lipid metabolism schematic . . . . . . . . . . . . . . . . . 31

2.1 Average hourly temperature and relative humidity during P2 . . . . 50

2.2 The effects of RAL treatment on DMI . . . . . . . . . . . . . 51

2.3 The effects of RAL treatment on milk yield . . . . . . . . . . . . 52

2.4 The effects of RAL treatment on plasma NEFA concentrations . . . . 53

2.5 The effects of RAL treatment on milk fat percentage . . . . . . . . 54

2.6 The effects of RAL treatment on feed efficiency (ECM) . . . . . . 55

2.7 The effects of RAL treatment on feed efficiency $(3.5 \%$ FCM) . . . . 56 
Effects of a commercial feed additive on production losses during acute heat stress conditions in mid-lactation Holstein dairy cows

Kerrie Davison

Dr. Waldron, thesis supervisor

\begin{abstract}
The objective of this study was to assess the effects of a commercial carbohydrate-based feed additive on dry matter intake (DMI), milk yield, milk composition, and plasma metabolites during an acute period of heat stress (HS). Forty-eight mid-lactation Holstein dairy cows were blocked according to milk yield, days in milk, and parity and were then randomly assigned to one of two dietary treatments within block. Treatments were calculated to provide 100g (as fed) daily of either sucrose (control; CTL) or a commercial feed additive (Rally ${ }^{\circledR}$, Purina Animal Nutrition, Shoreview, MN; RAL) administered twice daily as part of the total mixed ration (TMR). The experiment was divided into two periods consisting of $6.25 \pm 0.3 \mathrm{~d}$ under thermoneutral (P1) conditions, followed by $11.75 \pm 0.3 \mathrm{~d}$ of heat stress (P2) conditions (daily cyclical temperatures ranging from 23.8 to $30.2^{\circ} \mathrm{C}$, temperature-humidity index of 69.2 to 75.5$)$ in temperature-controlled environmental chambers. Daily DMI was determined using feed issue and refusal records. Milk yield was recorded daily and milk components were assessed for one 24-hour period on a twice weekly basis. Blood was sampled twice weekly and analyzed for concentrations of plasma glucose, $\beta$-hydroxybutyrate, insulin, and nonesterified fatty acids (NEFA). All variables were analyzed using the Mixed
\end{abstract}


procedure of SAS with repeated measures. There was no significant treatment difference during P1 for any of the variables measured. During P2, RAL cows displayed increased DMI (treatment by time, $P=0.05$ ) and milk yield (treatment by time, $P=0.05)$ relative to CTL cows. Milk fat percentage tended to decrease to a greater extent in cows fed RAL (treatment by time, $P<0.07$ ), but milk fat yield was not different between treatments $(P>0.20)$. Plasma NEFA concentrations of RAL cows tended to be lower $(P<0.1)$ than those of CTL cows during P2. Feeding RAL prior to and during a period of acute cyclical HS increased DMI and milk yield, and appeared to favor improved energy balance in heat-stressed mid-lactation dairy cows. 


\section{Chapter 1}

\section{Literature Review}

\section{$1.1 \quad$ Introduction}

This literature review aims to examine the effects of thermal stress on the physiology, production, and health of dairy cattle. First, the various definitions of heat stress and temperatures and temperature humidity indices at which heat stress occurs will be discussed. The physiologic and production responses of the cow (milk production and quality, reproduction, and health problems) will be briefly reviewed. Next, the effects of increasing global temperatures on the occurrence and economic significance of increasing days with heat stress will be examined. Energy balance and metabolic profiles of both early lactating cows and heat-stressed cows will then be examined to help understand the metabolic changes resulting from nutritional stress and the effects of heat itself. Finally, nutritional strategies designed to attenuate the deleterious effects of heat stress will be discussed. 


\subsection{Defining Heat Stress}

Heat stress occurs when any combination of environmental conditions cause the effective temperature of the environment to be higher than the thermoneutral zone of the cow (Armstrong, 1994). Effective temperature is largely determined by air temperature and relative humidity, but can also be modified by wind, precipitation, and solar radiation (Igono et al., 1992). Adverse environmental stressors exceeding threshold limits for the coping and compensatory mechanisms of the cow can compromise performance (production and reproduction) and health (Hahn, 1999). The lower critical temperature (LCT) is defined as the ambient temperature below which a homeotherm at rest must increase the rate of heat production in order to maintain thermal balance. The upper critical temperature (UTC) is defined as the ambient temperature above which thermoregulatory evaporative heat loss processes are initiated. The thermoneutral zone represents the ambient temperature range between the LCT and UTC (Igono et al., 1992; Figure 1.1).

\subsubsection{Physiological Response to Heat Stress}

The ability of a cow to maintain homeothermy (internal body temperature within the normal range) decreases when the ambient temperature rises above the UCT. Increasing air temperature reduces the temperature differential between the body temperature of the cow and that of the ambient temperature; consequently heat transfer to the environment decreases (West et al., 2003). Non-evaporative heat loss

declines as ambient temperatures rise above the UCT, and cows become increasingly 
dependent upon peripheral vasodilation and water evaporation to dissipate heat and prevent a rise in body temperature (Berman et al., 1985). Although ambient temperature hinders non-evaporative cooling processes, humidity has the ability to compromise the ability of the cow to utilize evaporative cooling processes. As a result, cows in hot and humid environments are at greater risk for heat stress.

Once the ambient temperature exceeds thermoneutral conditions, cows first attempt to compensate by increasing evaporative cooling mechanisms. This cooling primarily occurs via evaporation from the body surface (i.e., sweating) with minor losses coming from the respiratory tract. Evaporative losses from the skin begin to increase above $20^{\circ} \mathrm{C}$ (Berman, 1968). In an attempt to compensate for the increased heat load and subsequent increase in evaporative cooling mechanisms, cattle increase their water consumption (Beatty et al., 2006). Howden and Turnpenny (1997) developed a model to simulate water requirements for Bos indicus cattle, specifically in the Brahman breed, as mean ambient temperature increases. Based on this model they determined that there was a strong linear correlation between temperature and water consumption. For example, Brahman cattle drink 20.5 L per day at $17^{\circ} \mathrm{C}, 29.6 \mathrm{~L}$ per day at $24^{\circ} \mathrm{C}, 40 \mathrm{~L}$ per day at $32^{\circ} \mathrm{C}$, and $47.8 \mathrm{~L}$ per day at $38^{\circ} \mathrm{C}$. McDowell et al. (1969) report that water consumption increased $28 \%$ at $32.2^{\circ} \mathrm{C}$ compared to thermoneutral conditions. This increase in water consumption helps offset water losses from evaporative cooling. In addition to increasing consumption, cows also draw water from feces in an attempt to supply evaporative cooling needs (McDowell et al., 1969).

The skin represents a significant heat loss organ and has the capacity to utilize both evaporative and non-evaporative heat loss mechanisms. The skin is able to 
dissipate up to $25 \%$ of the heat load of a cow; this percentage varies according to the breed and the individual's genetics (Johnston et al., 1958). Evaporative cooling is limited in its ability to dissipate heat, especially in humid environments.

Therefore, non-evaporative cooling mechanisms such as panting and increased tissue heat conductance become increasingly important as ambient temperatures rise above the UCT. Finch et al. (1982) reported that at an ambient temperature of $25^{\circ} \mathrm{C}$, non-evaporative heat loss represents approximately 55 to $65 \%$ of total heat loss from the skin. Evaporative cooling was only able to dissipate 35 to $45 \%$ of the heat load at $25^{\circ} \mathrm{C}$ and this percentage declined as ambient temperature approached skin temperature. Although heat loss mechanisms shift from evaporative to non-evaporative as ambient temperature increases, heat-stressed cows are still unable to dissipate $100 \%$ of the heat gained from the environment as indicated by increases in core body temperature. Regardless of increased sweating, increased water consumption, and non-evaporative cooling mechanisms, heat stress has the ability to overwhelm the ability of the cow to fully compensate and results in clinical signs of heat stress.

Clinical signs of heat stress include open-mouth panting, drooling, reluctance or inability to rise, increased licking of coat, and general dullness including neurological signs with staring and glazed eyes (Beatty et al., 2006). When evaporative cooling mechanisms become inadequate, respiratory rate increases as animals attempt to maintain homeothermy (Hahn, 1999). This results in decreased $\mathrm{pCO}_{2}$ and $\mathrm{H}_{2} \mathrm{CO}_{3}$ in the venous blood and blood $\mathrm{pH}$ decreases. The end result, if heat stress continues, is respiratory alkalosis resulting in metabolic acidosis (Beatty et al., 2006). Clinical signs at the farm level include decreased milk production, decreased milk fat and 
protein content, decreased reproductive efficiency, health problems and even death; costing the US dairy industry $\$ 1$ billion annually (St. Pierre et al., 2003).

\subsubsection{Ambient Temperatures vs. Temperature Humidity Index}

Traditionally, heat stress research has focused on the singular effect of ambient temperature on production losses in dairy cows. Berman et al. (1985) reported that body temperature began to increase above an ambient temperature of 25 to $26^{\circ} \mathrm{C}$ for high producing dairy cows. Thus they define the UCT for heat stress as 25 to $26^{\circ} \mathrm{C}$ regardless of humidity. However, ambient temperature as a measure of heat stress fails to take into account the added stress of humidity, therefore the temperature-humidity index (THI) is commonly used to evaluate heat stress (Bohmanova et al., 2007; Armstrong, 1994). Temperature-humidity index is a single value that reflects the combined effects of air temperature and humidity. Humidity is an important factor, as the air water vapor content has an impact on evaporative losses from the skin and lungs. Increased humidity in a hot environment significantly compromises evaporative heat loss (Bohmanova et al., 2007).

Armstrong (1994) utilized THI values to identify four critical heat stress zones for dairy cattle, defining the zones as follows: a THI $\leq 71$ represents no thermal stress, the so called comfort zone, 72 to 79 equates to mild thermal stress, 80 to 88 indicates moderate thermal stress, and $\geq 90$ constitutes severe thermal stress (Figure 1.2). Lemerle and Goddard (1986) defined three critical heat stress zones where THI 70 to 75 is considered comfortable, 75 to 78 is mildly stressful and cows must employ costly heat dissipating mechanisms to maintain normothermy, and > 
78 cause extreme distress and the cow is unable to maintain normal body temperature. Recent studies suggest that heat stress may begin at a THI of $<70$, as Bouraoui et al. (2002) reported that milk yield decreased by $0.41 \mathrm{~kg}$ per cow per day for each unit increase in THI above 69. This may be a result of genetic selection for increasingly high producing animals resulting in a decreased ability to compensate for metabolic heat, thus decreasing the minimum THI threshold. In addition to the onset of heat stress at a lower THI, each unit of THI appears to have a more significant effect on animal well-being (Bouraoui et al., 2002). Vitali et al. (2009) reported that the number of deaths at dairy farms start to increase once THI exceeds 71. Additionally, their data suggest that a THI of $>80$ is the lower limit at which heat stress threatens survival. Although THI is considered to be a more accurate representation of heat stress than ambient temperature, there are many different equations to calculate the THI and each differs in its ability to detect heat stress (Dikmen and Hansen, 2009). Bohmanova et al. (2007), created 15 THI indices (numbered THI 1 to THI 15) to analyze heat stress conditions in Athens, Georgia and Phoenix, Arizona. They reported large differences in thresholds of heat stress among indices and between regions, ranging from 68 for THI 1 in Athens, to 83 for THI 14 in Phoenix. They determined that indices with higher weights placed on humidity were best in a humid climate as the humidity can reach levels that could compromise evaporative cooling. For example, in Georgia the relative humidity stays above $70 \%$ for $67 \%$ of the year, whereas in Arizona it does not exceed a maximum of $47 \%$. They concluded that indices with larger weights on temperature were best in semi-arid climates as ambient temperature represents the limiting factor of heat stress. Thus one must be judicious when selecting which THI 
equation to use, and ensuring that it is appropriate for the local climate.

\subsection{Effects of Heat Stress on Production}

\subsubsection{Effects on Reproduction}

Heat stress has significant effects on fertility, embryonic mortality, and non-return rates (proportion of cows not seen to come into estrus after breeding) in dairy cows. Ingraham et al. (1974) reported that an average daily THI $<70$ at 2 days prior to breeding was associated with a significant decline in conception rate in Holstein cows. At THI $=70$, the conception rate was $55 \%$, but decreased to $10 \%$ when THI increased to 84. In another study, Ingraham et al. (1976) reported that conception rates declined from 66 to $35 \%$ as the THI increased from 68 to 78 . This represented a $4.7 \%$ decrease per unit increase in THI. In addition to decreasing conception rate, heat stress also has been shown to reduce conceptus weight and substantially increase embryonic mortality (Biggers et al., 1987; Stott and Williams, 1962). Decreased breeding efficiency during the summer months results from the low rate of fertilization and high rate of embryonic mortality associated with high ambient temperature and humidity. Cows that do not become pregnant during the summer months create future deficiencies in early lactation cows in the following spring (Ray et al., 1992).

Reproductive efficiency and non-return rate decrease during heat stress, especially in first lactation cows (Ray et al., 1992). Reproductive efficiency takes into account calving interval length and number of services per conception (number 
of times a cow is bred before she falls pregnant) whereas non-return rate represents the proportion of cows presumed pregnant following breeding. Ray et al. (1992) studied the effects of thermal stress on reproductive efficiency using data collected from the Arizona DHIA, which represented 19,266 Holstein cows over a 5 year period. They reported that cows calving in the spring and summer had both an increased calving interval and increased services per conception, indicating that reproductive efficiency was compromised during thermal stress. First parity cows appeared to be more susceptible to heat stress as they had decreased reproductive efficiency compared to multiparous cows. Heat-stressed first parity cows also appeared to give priority to growth and body maintenance over milk production, thus compromising their performance during their first lactation. In addition to decreasing reproductive efficiency, heat stress has also been shown to decrease non-return rate. Ravagnolo and Misztal (2002) examined the effects of increased THI on non-return rate at 45 days (NR45) in cattle in Florida, Georgia, and Tennessee. They reported that on average the NR45 remained stable until THI reached 68, at which point NR45 decreased by 0.005 per unit increase of THI on the day of insemination. First lactation cows had the same average THI 68 threshold, but were more sensitive to each unit increase in THI as NR45 decreased by 0.008 per unit increase in THI. These authors also reported that the average THI threshold for sensitivity was different depending on the state studied with Florida, Georgia, and Tennessee having NR45 THI thresholds of 70, 70, and 66, respectively. These thresholds are economically significant as, for example, dairy cattle in Georgia are exposed to a THI $>72$ for approximately 138 days annually; thus indicating that reproduction is significantly effected for 138 days during the year. 


\subsubsection{Effects on Milk Production and Quality}

In response to increase daytime temperatures, cows change their feeding hours and patterns in an attempt to avoid the heat. Heat-stressed cows consume less feed during the hot period of the day, and consume a greater proportion of their dry matter intake (DMI) in the cooler nighttime hours (Ominski et al, 2002). However, in order for cows to dissipate all of the heat gained from the previous day, the nighttime ambient temperature must drop below $21^{\circ} \mathrm{C}$ for a minimum of 3 to 6 hours (Igono et al., 1992; Muller et al., 1994a; Muller et al., 1994b). During the summer months, nighttime temperatures may not fall below this threshold, and cows are not able to compensate at night for decreased DMI during the day. This is reflected in the fact that overall DMI decreases anywhere from 9.6 to $35 \%$ during heat stress (Bouraroui et al., 2002; Rhoads al., 2009). This decreased DMI, however, only accounts for 35 to $50 \%$ of the reduction in milk yield, indicating that other mechanisms in addition to decreased nutrient intake are responsible for the milk production losses reported during heat stress (Rhoads et al,. 2009; Wheelock et al., 2010).

Milk production begins to decrease once ambient temperature and THI exceed a minimum critical value. Igono et al. (1992) defined the critical minimum, maximum, and mean ambient temperatures effecting milk production for lactating Holstein cows as 21,32 , and $27^{\circ} \mathrm{C}$, respectively. Milk production declined markedly when the minimum THI was $>64$, the maximum THI $>76$, or the mean THI $>72$. Thus the critical minimum, maximum and mean THI values for milk yield are 64, 76 , and 72 respectively (Igono et al., 1992). In a study by Ravagnolo and Misztal 
(2000), when THI exceeded 72, daily milk yield decreased $0.2 \mathrm{~kg}$ per unit of THI increase. Bouraoui et al. (2002) reported that, when THI increased from 69 to 78, milk production decreased by $21 \%$ and daily milk yield decreased by $0.41 \mathrm{~kg}$ per cow for each unit increase above 69 . Milk yield appears to be most affected by the THI and mean air temperature two days prior, and thus decreased milk yield due to heat stress appears to have a two day lag period (West et al., 2003).

Not only is milk production reduced during heat stress, but milk quality is also affected by increased THI. During the summer months Bournaoui et al. (2002) reported that milk fat decreased from 3.58 to $3.24 \%$, and milk protein decreased from 2.96 to $2.88 \%$, from spring to summer respectively. These decreases in milk fat and protein are economically significant, as milk fat and protein represent the more valuable milk components, and lower percentages could reflect decreased revenue for the producer. This decreased milk fat and protein represents more than just seasonal changes, and rather reflects the effects of increased temperature and THI. Bandaranayaka and Holmes (1976) reported that both the protein and fat content of milk decreased when ambient temperature exceeded $30^{\circ} \mathrm{C}$. In addition to decreased milk fat, they also reported that the proportion of short chain fatty acids in the milk decreased. More recently Ravagnolo and Misztal (2000) reported that milk fat and protein remain steady until the THI exceeds 72 . Above a THI of 72 , average milk protein decreased by $0.009 \mathrm{~kg}$ per unit increase in THI. Average milk fat decreased at a slightly higher rate than milk protein, with a $0.012 \mathrm{~kg}$ decrease per unit increase in THI.

Heat stress also compromises mammary gland development during the dry period, which in turn leads to changes in milk quality. Tao et al. (2011) reported 
that heat stress decreased mammary cell proliferation rate and resulted in decreased milk production in the subsequent lactation. Cows that experienced heat stress during their dry period produced $5 \mathrm{~kg}$ per day less milk than cows housed in thermoneutral conditions during their dry period. These authors also observed that when cows were heat-stressed in the dry period milk protein decreased from 3.01 to $2.87 \%$, milk fat tended to decrease, and the linear somatic cell score increased (3.35 vs., 2.94), indicating decreased mammary health.

\subsubsection{Genetics and Response to Heat Stress}

The ability of a cow to dissipate heat and maintain production during heat stress varies depending on the breed and individual genetics of the individual animal. In particular, Bos indicus cattle breeds are considered to be more heat tolerant than their Bos taurus counterparts. Examples of Bos indicus breeds include Brahman, Gyr, Nebu, and Sindhi. Common Bos taurus beef breeds include the Angus, Hereford, and Shorthorn, whereas the two most common Bos taurus dairy breeds are the Holstein and Jersey. Beatty et al. (2006) compared Bos taurus and Bos indicus responses to heat stress and reported that when both breeds were subjected to the same environmental conditions, Bos taurus cattle had reduced DMI and had more significant and prolonged blood acid-base and electrolyte imbalances compared to Bos indicus cattle. Many mechanisms have been proposed to explain the superior heat tolerance seen in Bos indicus breeds, including a greater sweating response, lower basal heat production, and larger surface area (Finch et al., 1982; Johnston et al., 1958; McDowell et al., 1996). 
Sweating response, which is the linear slope of the relationship between mean rectal temperature and sweating rate, has been shown to differ between Bos indicus and Bos taurus cattle. Finch et al. (1982) compared the sweating rates among Brahman, Brahman-Hereford crosses, Hereford-Shorthorn crosses, and Shorthorns. They determined that Brahman cattle had the greatest sweating response and that this response was unaffected by environmental heat. This may indicate that Brahman cattle have both a higher intrinsic sweating response and that they rely on other adaptations to dissipate excess heat. Brahman cattle also have a $12 \%$ greater surface area per unit of body weight than Bos taurus cattle which allows for a greater proportion of heat to be lost from the skin (Kibler and Brody, 1950). Bos indicus-Bos taurus crossbreeds also appear to demonstrate superior heat tolerance. In a study conducted by Johnston et al. (1958), Sindhi-Holstein crosses were reported to have lower total heat production and to produce less heat per unit of body weight or unit of surface area than Holsteins or Jerseys. The Sindhi-Holstein crosses also demonstrated superior heat tolerance as evidenced by lower body temperatures and respiration rates during heat stress. Taken together, these studies suggest that the superior heat tolerance seen in Bos indicus cattle results from a superior sweating response, lower basal metabolic rate and an a larger surface area relative to body weight. These mechanisms allow for greater heat dissipation through both evaporative and non-evaporative cooling.

While the ultimate goal of utilizing Bos indicus-Bos taurus crosses is to generate a high producing heat tolerant cow, Bos indicus cattle appear to have inherent characteristics that limit milk yield. McDowell et al. (1996) compared production data between zebu-dairy breed crosses in selected areas of Asia, Africa, and Latin 
America. They reported that the F1 generation produced greater than $100 \%$ more milk than pure zebu cattle, but these cattle did not reach their estimated mean genetic potential of 3,000 to $3,800 \mathrm{~kg}$ of milk per lactation. Additionally, these authors estimated that the marginal level of milk yield per cow needed to support commercial dairying was $4,400 \mathrm{~kg}$ in the areas studied. Thus while the first generation crosses possessed superior milk production compared to zebu cattle, they were not economically viable. Even in Bos indicus crossbred cattle, metabolic heat production is positively correlated with increased milk yield. Johnston et al. (1958) reported that with each increase in $1 \mathrm{lb}$ of fat-corrected milk, the heat increment increased by $10 \mathrm{kCal} / \mathrm{hr}$ in Red Sinhi-Holstein cattle. This suggests that selecting for high producing Bos indicus crosses will increase their heat production due to increases in basal metabolism, thus reducing heat tolerance in these cattle. Thus it may be difficult to combine traits of good heat adaptation and high metabolic potential in cattle. Since Bos indicus-Bos taurus cross breeds yield variable production results, research is also focusing on differences in heat tolerance within the Holstein and Jersey breeds. Variation in the onset of heat stress (as defined by decreased milk yield) exists in the US Holstein population. Some of this variation can be explained by differences in the genetic heat tolerance of the individual cows, as there is a strong genetic correlation between milk yield and yield decay during heat stress (Sanchez et al., 2009). Ravagnolo and Misztal (2000) modeled heat tolerance in Holstein cattle in Georgia and reported antagonistic correlations between milk yield and heat tolerance. They reported that for heat-humidity indices below 72 , heritability for milk was 0.17 , and additive variance of heat tolerance was 0. For a heat-humidity index of 86 (which would correspond to temperatures of 
$36^{\circ} \mathrm{C}$ at $50 \%$ humidity), the additive variance of heat tolerance was as high for general effect, and the genetic correlation between the two effects was 0.36 . They concluded that current selection for production reduces heat tolerance. Genetic influence during heat stress is not only limited to milk production, but also is evident in reproduction efficiency. Oseni et al. (2004) examined the effects of genetic parameters on days open accounting for heat stress. They reported substantial genetic variability in number of days open related to heat stress. Within this model, they reported that cows fall on a continuum for reproductive efficiency during heat stress. Although current selection processes appear to reduce heat tolerance, joint selection for both heat tolerance and production is possible (Ravagnolo and Misztal, 2000).

\subsection{Impact of Climate Change on Dairy Production}

Global warming is predicted to increase production losses resulting from heat stress. Average global temperature has increased $0.044^{\circ} \mathrm{C}$ per decade from 1861 to 2000. However, the most marked increase in average global temperature has occurred in the most recent decades. From the 1970's to 2000, average global temperature has increased by $0.165^{\circ} \mathrm{C}$ per decade, with temperatures increasing at a higher rate in the Northern hemisphere compared to the Southern hemisphere (Table 1.1). Figure 1.3 shows the trends in annual hemispheric and global temperatures over the past 150 years. Although the southern hemisphere does not appear to be warming quite as rapidly as the northern hemisphere (Table 1.1), average global temperatures are nonetheless on the rise. In Queensland, Australia, 
the number of days that exceed a THI of 80 has increased significantly over the past 40 years. Howden and Turnpenny (1997) created a climate change model based on the Australian CSIRO scenario $\left(2 \times \mathrm{CO}_{2}\right.$, doubling of atmospheric $\left.\mathrm{CO}_{2}\right)$, which suggested a $2.76^{\circ} \mathrm{C}$ increase in temperature in Queensland, Australia by 2100. Under current climate conditions, THI exceeded 80 approximately $16 \%$ of the year, but under the climate change scenario THI would exceed 80 on $38 \%$ of days. This THI represents the lower limit at which heat stress compromises survival described by Vitali et al. (2009) and thus poses a real threat to cattle.

Global warming is not only responsible for increasing ambient temperatures worldwide, but it also may result in the frequency of extreme weather events. For example, in 2006, a heat wave in California resulted in the deaths of over 20,000 cows and forced the dairy industry to request over $\$ 1$ billion in disaster relief (Calif. Dep. Food Agric. 2006). Additionally, the 2011 heat wave in Iowa reportedly caused 4,000 beef cattle deaths in (Drovers Cattle Netw. 2011).

\subsection{Energy Balance}

Genetic selection for high-producing cows has increased the rate of US milk production by approximately $2 \%$ per cow per year since 1985 (Dillon et al., 2006). However, this continued selection for production increases metabolic load. Negative energy balance (NEBAL) occurs when the energy needed (for maintenance, growth, reproduction, lactation etc.) exceeds energy input. In order to meet their energy requirement, the cow catabolizes body tissue, predominantly from fat reserves (Banos et al., 2005). This NEBAL is most apparent in periparturient or transition 
cows, where feed intake lags behind milk production. During this transition period, intake is insufficient to meet the energy demands of lactation, resulting in a state of NEBAL (Van Arendonk et al., 1991). Beerda et al. (2007) reported that cows with high genetic merit for milk yield were more prone to preferentially utilize fat reserves for milk production, and consequently had decreased post-partum body condition score (BCS) compared to cows with low genetic merit for milk yield. Concentrations of $\beta$-hydroxybutyrate (BHBA) and nonesterified fatty acids (NEFAs) are correlated with NEBAL, whereas glucose and insulin are correlated with positive energy balance (PEBAL). Cows may enter NEBAL during the transition period, periods of low nutrient availability, and heat stress.

\subsubsection{Effects of Heat Stress on Energy Balance}

Under thermoneutral conditions, metabolic heat production is sufficient to maintain normal internal body temperature and any excess is transported to the skin where it is exchanged with the environment. This process is complicated during

heat stress, when the temperature gradient between the cow and the environment is reduced. In addition to reducing passive heat loss from the skin, rising ambient temperatures increase the external thermal load on the cow. In order to dissipate the excess heat and avoid a positive heat balance, the cow must resort to more energetically costly heat loss mechanisms such as sweating and panting. The ambient temperature beyond which the body temperature starts increasing is determined by both the maximum evaporative capacity of the animal and its tissue insulation (Berman, 2004). 
Thermal insulation is suspected to be an important factor in calculating the effects of heat stress on maintenance energy requirements. Thermal insulation represents the combination of tissue insulation (TI) and external insulation (EI). TI represents the resistance to heat flow from body core to skin and EI is the resistance to heat flow from skin to air. The sum of TI and EI determines the thermal insulation of the cow (Berman, 2004). The effect of the body condition of the animal and thus the distribution of subcutaneous fat (representative of tissue insulation) on energy requirements has been studied in beef cattle at temperatures below the LCT, but there are no published estimates of tissue insulation changes at ambient temperatures above LCT in cattle. Thompson et al. (1983) reported that in Angus-Hereford cows with the same body mass, animals with more fat had lower daily energy requirements in the winter. However, there was no difference in daily energy requirement in Angus-Holstein crosses. This may be due in part to the fact that Holstein cows have less subcutaneous fat than beef breeds. This may suggest that beef cows with greater subcutaneous fat may have a greater maintenance energy requirement during heat stress due to increased insulation, but whether this also affects Holstein cattle is unknown.

A number of different equations have been proposed to calculate maintenance energy balance in heat-stressed cattle, but a universally accepted equation does not yet exist. The National Research Council estimates that maintenance energy requirements increase by 7 to $25 \%$ (for a $600 \mathrm{~kg}$ cow) during heat stress as a result of increased non-evaporative cooling mechanisms. However it is not known how accurately this estimate reflects the true energy requirements. Moore et al. (2005) demonstrated the difficulty in calculating energy balance (EBAL) during heat 
stress. In this study cows were calculated to be in PEBAL according to the equation $\mathrm{EBAL}=$ net energy intake - (net energy for maintenance + net energy for lactation). The net energy intake was calculated by multiplying DMI by net energy of the diet plus net energy value of the supplement. Net energy for maintenance was calculated to increase by $20 \%$, which, unlike the NRC, was designed to take into account the decrease in milk yield during heat stress. However, despite this calculated PEBAL the cows lost approximately $18 \mathrm{~kg}$ of BW during the trial, which would indicate that the cows were in fact in NEBAL. Rhoads et al. (2009) conducted a trial in which control cows housed in thermoneutral conditions were restricted fed to match the intakes of heat-stressed cows. When the EBAL was calculated, both pair-fed and heat-stressed cows had reduced EBAL, but only the pair-fed cows had a mean NEBAL. Whereas only the pair-fed cows had a mean negative EBAL (6.83 vs. $6.99 \mathrm{Mcal} / \mathrm{d}$ ), both groups of cows lost $50 \mathrm{~kg}$ of body weight, suggested that the heat-stressed cows were experiencing NEBAL. The search for a universal equation to adjust for increased maintenance costs in heat-stressed cows is further complicated by the difficulties in predicting UCT (Fox and Tyluki, 1998). Currently, heat-stressed cows are considered to be in NEBAL based on BW and body condition loss, but their exact energy balance status is unknown. This indicates that more research needs to be conducted in this field in order to quantify more accurately the energy costs associated with heat stress. 


\subsubsection{Metabolites and Lactation-induced NEBAL}

Ruminants, unlike monogastrics, depend primarily on hepatic gluconeogensis to meet their tissue glucose demands (Reynolds, 2006). Propionate produced from ruminal and hindgut fermentation is the main glucose precursor with others including amino acids, lactate, and glycerol (Stangassinger and Giesecke, 1986; Ballard, 1965; Drackley et al., 2001). Glucagon, cortisol, norepinephrine, and epinephrine are catabolic hormones that promote gluconeogensis and adipose tissue lipolysis. Lipolysis results in the release NEFAs, which can then be oxidized by $\beta$-oxidation to produce energy. These hormones are generally considered to be energy mobilizing hormones as they promote glucose production and NEFA oxidation (Brockman, 1978; Beede and Collier, 1986). In contrast, insulin is an energy storing hormone that stimulates lipogenic enzyme expression and increases lipogenesis in both hepatic and adipose tissue (Bauman and Currie, 1980; Koo et al., 2001). Insulin release can be stimulated by both elevated blood glucose or propionate levels and promotes energy storage. Insulin not only suppresses NEFA mobilization, but it also inhibits hepatic $\beta$-oxidation of NEFA (Drackley et al., 2001). Propionate, glucose, and acetate also inhibit hepatic $\beta$-oxidation (Jesse et al., 1986). Lipid metabolism represents a balance between the anabolic effects of insulin and catabolic effects of cortisol, glucagon, norepinephrine, and epinephrine.

The mammary gland is dependent on glucose for lactose synthesis. Lactose is the major osmotic regulator of milk and generally constitutes between 4.4 and $5.2 \%$ of

the milk (Peaker, 1977; Morrissey, 1985). A maximally secreting mammary gland requires up to $80 \%$ of the total glucose turnover, indicating that the vast majority of 
circulating glucose is taken up by the gland for lactose synthesis (Bauman and Currie, 1980). Demands for glucose increase sharply at calving as the cow transitions from a non-lactating to a lactating state. However, during the first $21 \mathrm{~d}$ post-calving the demand for glucose and amino acids exceeds the supply and the cow enters into a state of NEBAL (Overton, 2004; Drackley et al., 2001). Figure 1.4 depicts the demand for glucose compared to available glucose during the periparturient period. For the three weeks preceding parturition the glucose supply exceeds the glucose demand; however, by three days prior to parturition, the glucose supply rapidly decreases (due to decreased DMI). After parturition, lactation commences and the glucose demand continues to increase while the supply lags behind. Increased glucose demand decreases blood glucose levels and insulin secretion decreases. In addition to decreased insulin secretion, peripheral insulin resistance also increases during NEBAL, which in turn leads to decreased glucose uptake by the peripheral tissues (Baumgard et al., 2006). In the absence of insulin, proteolysis and lipolysis are promoted which leads to increased mobilization of glucose (from glycogenolysis), NEFA, and amino acids to the peripheral tissues. Mobilized NEFA are then available to the mammary gland, muscle, and liver for oxidation, thus supplying these tissues with an alternate energy substrate to glucose (Overton and Waldron, 2004; Brockman, 1978; see Figure 1.5). Ketone bodies (which include $\beta$-hydroxybutyrate [BHBA], acetone, and acetoacetate) are the intermediate metabolites of fatty acid oxidation and result from incomplete oxidation of NEFA to acetyl-CoA. As the NEFA supply exceeds the ability of the liver to completely oxidize the fatty acids, ketone production increases and results in elevated plasma ketone levels. BHBA is the predominant ketone present in the 
blood and thus, is most often used to assess ketone status in the animal (LeBlanc, 2010). These NEFA concentrations reflect the magnitude of fat mobilization from storage and circulating levels of both NEFA and BHBA are commonly used indices of NEBAL in lactating dairy cows (Ospina et al., 2010; Leblanc 2010).

\subsubsection{Metabolites During Heat Stress Induced NEBAL}

Although heat-stressed cows appear to be in a state of NEBAL, they have a different metabolic profile compared with cows with lactation-induced or nutritional NEBAL. Several studies have examined the effects of thermal load on milk production, DMI, and plasma metabolites by using pair-fed controls (Wheelock et al., 2010; Rhoads et al., 2009; Shwartz et al., 2009). In each of these studies, pair-fed cows housed in thermoneutral conditions (PFTN cows) had their DMI adjusted to mimic their heat-stressed counterparts in order to isolate the effects of heat. Thus, PFTN cows were maintained on the same nutritional plane as the heat-stressed cows. Although heat-stressed cows in all three studies entered into NEBAL (as evidenced by BCS and weight loss), their plasma NEFA levels did not change. Their PFTN counterparts, in contrast, had a $120 \%$ increase in NEFA (Rhoads et al., 2009). This is particularly interesting as one would expect that as these cows were in NEBAL that they would also mobilize NEFA in order to meet energy demands. Heat-stressed cows also had increased circulating cortisol, epinephrine, and norepinephrine levels. These hormones typically increase lipolysis

and NEFA mobilization, yet NEFA levels remain unchanged even in the presence of these catabolic hormones (Beede and Collier, 1986). Rhoads et al. (2007) postulate 
that this shift away from $\beta$-oxidation may be an evolutionary mechanism to help survive an increased heat load since $\beta$-oxidation of lipids is an exothermic process.

Shwartz et al. (2009) examined the difference in glucose and insulin kinetics in

heat-stressed and PFTN cows. Heat stress decreased the circulating plasma glucose, but it had no effect on the glucose disposal rate. Both basal and peak insulin levels also increased during the heat stress period, which is likely responsible for the ability of the heat-stressed cow to maintain glucose disposal. In contrast, PFTN cows had no change in their insulin levels and demonstrated an impaired ability to dispose of glucose. These findings in control cows agree with the decreased peripheral insulin sensitivity, and thus decreased glucose disposal that is typically seen in underfed animals. Glucose tolerance test data also suggest that heat-stressed cows have an increased glucose pool entry, which when coupled with decreased plasma glucose, may indicate that glucose, versus NEFA, is the preferred fuel during heat stress. Wheelock et al. (2010) and Rhoads et al. (2009) reported that heat-stressed cows produce between 200 and 400 g less lactose compared to their PFTN controls, suggesting that glucose is preferentially used by tissues other than the mammary gland. Thus heat-stressed cows appear to suppress lipid mobilization during NEBAL, instead shifting towards carbohydrate oxidation in an attempt to meet daily energy needs.

\subsection{Nutritional Strategies}

As a result of the high economic losses resulting from heat stress, researchers are investigating strategies to reduce the burden of heat stress on the cow. Such areas 
of focus include improving cooling systems, genetic selection for more heat tolerant cows, and improving nutrition. Of particular interest to this review are possible nutritional strategies to mitigate production losses during thermal stress. During heat stress, cows experience decreased nutrient intake resulting from decreased DMI, and demonstrate changes in post-absorptive energy metabolism. Thus nutritional strategies have been designed to target multiple pathways including: stimulating DMI, increasing milk synthesis by increasing dietary energy, increasing milk production and DMI indirectly by decreasing metabolic heat production, and increasing the extraction of dietary energy.

Moallem et al. (2010) examined the effects of increasing either the fat or carbohydrate (in the form of grain) content of the diet in heat-stressed cows to generate a dietary energy density $<1.75 \mathrm{MCal} / \mathrm{kg}$ for both treatments. Cows supplemented with fat appeared to channel nutrients towards milk fat production, resulting in increased fat-corrected milk whereas grain-supplemented cows appeared to channel more nutrients towards body fat deposition and as a result had lower milk fat. Grain-supplemented cows had greater a plasma glucose concentration, whereas fat-supplemented cows had high plasma NEFA levels. Although fat supplementation increased production efficiency compared to grain-supplemented cows, neither dietary treatment was effective in enhancing milk production as increasing the total energy content of the diet above $1.75 \mathrm{MCal} / \mathrm{kg}$ suppressed DMI. Drackley et al. (2003) also examined the effects of increasing dietary energy via high fat or increased starch-based concentrate. Both diets were isocaloric at 1.60 Mcal of NEL. Similar to Moallem et al. (2010), Drackley et al. (2003) reported that starch-supplemented cows had increased plasma glucose levels and fat-supplemented 
cows had increased plasma NEFA. Fat-supplemented cows had increased milk fat, but high fat decreased milk protein. Starch-supplemented cows had increased DMI and milk protein content compared to the high fat cows. Milk fat was higher in fat-supplemented cows than the starch-supplemented cows, however increasing dietary energy resulted in decreased milk fat for both diets. While milk fat production increases milk quality, it is a costly energetic process and may contribute to the NEBAL of a heat-stressed cow. Conjugated linoleic acids (CLA) have been shown to depress milk fat production, leading Moore et al. (2005) to theorize that the addition of CLA to the ration of heat-stressed cows might allow for partitioning of nutrients towards milk production and other milk components. They reported that CLA did indeed depress milk fat and increase energy availability; however, CLA had no effect on rectal temperature, respiration rate or other production parameters. Although neither high fat nor high carbohydrate diets appear to have the ability to alleviate the production losses resulting from heat stress, it is interesting to note the difference in nutrient partitioning between diets. High fat supplementation appears to shift post-absorptive mechanisms away from carbohydrate oxidation, however, it is unknown whether this relates to increased metabolic heat production.

In addition to increasing the energy content of the diet, other studies have examined the benefits of adding dietary supplements such as yeast cultures or niacin. Shwartz et al. (2009) postulated that since heat-stressed cows appear to have a shift in post-absorptive glucose and lipid metabolism, feeding a yeast culture (YC) containing fibrolytic enzymes would increase dietary energy extraction and thus attenuate decreased milk synthesis. While YC cows had a reduced body 
temperature, the $\mathrm{YC}$ was unable to prevent production losses during heat stress. Another study conducted by Zimbleman et al. (2010) examined the effects of encapsulated niacin, a B-vitamin known to facilitate vasodilation and increase blood flow in the skin, on production parameters and body temperature during heat stress. Even though niacin-treated cows had decreased rectal temperatures and increased evaporative loss during heat stress, milk yield and DMI were unaffected.

Although there are many nutritional strategies designed to target production losses during heat stress, efficacy varies greatly between products and individual studies. As of yet there is no single nutritional strategy that has the ability to prevent the decreased milk production, milk quality, and DMI seen during heat stress. Due to the significant economic costs resulting from heat stress, more research needs to be conducted in order to develop a nutritional strategy to decrease the effects of heat stress on the lactating dairy cow. 


\subsection{Tables for Chapter 1}

Table 1.1: Temperature changes explained by the linear trend over several periods for the combined land and marine hemispheric and global data set (HadCRUT2v). Trends are expressed in ${ }^{\circ} \mathrm{C}$ decade- 1 and in bold if significant as the $95 \%$ significance level (Jones and Moberg, 2003).

\begin{tabular}{lcccrc}
\hline \hline Series & $1861-2000$ & $1901-2000$ & $1920-44$ & $1945-76$ & $1977-2001$ \\
\hline NH & $\mathbf{0 . 0 4 2}$ & $\mathbf{0 . 0 6 5}$ & $\mathbf{0 . 1 5 2}$ & $-\mathbf{0 . 0 5 1}$ & $\mathbf{0 . 2 2 3}$ \\
SH & $\mathbf{0 . 0 4 5}$ & $\mathbf{0 . 0 6 7}$ & $\mathbf{0 . 1 5 7}$ & 0.041 & $\mathbf{0 . 1 0 6}$ \\
Global & $\mathbf{0 . 0 4 4}$ & $\mathbf{0 . 0 6 6}$ & $\mathbf{0 . 1 5 4}$ & -0.005 & $\mathbf{0 . 1 6 5}$ \\
\hline
\end{tabular}




\subsection{Figures for Chapter 1}

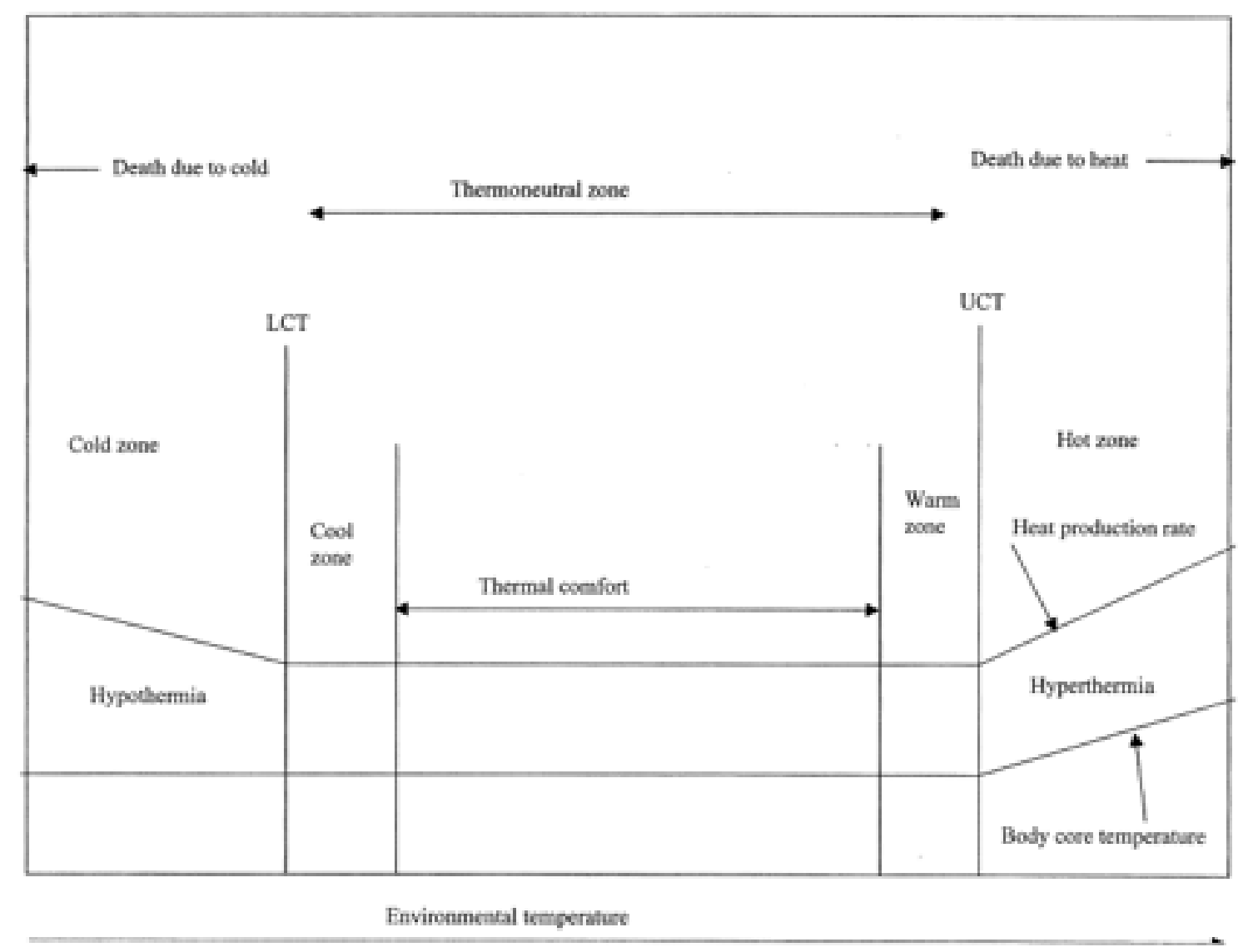

Figure 1.1: Schematic relationship of the core body temperature of the animal, heat production, and environmental temperature. LCT = Lower critical temperature; UTC $=$ Upper critical temperature. Taken from Kadzere et al. (2002). 
RELATIVE HUMIOITY

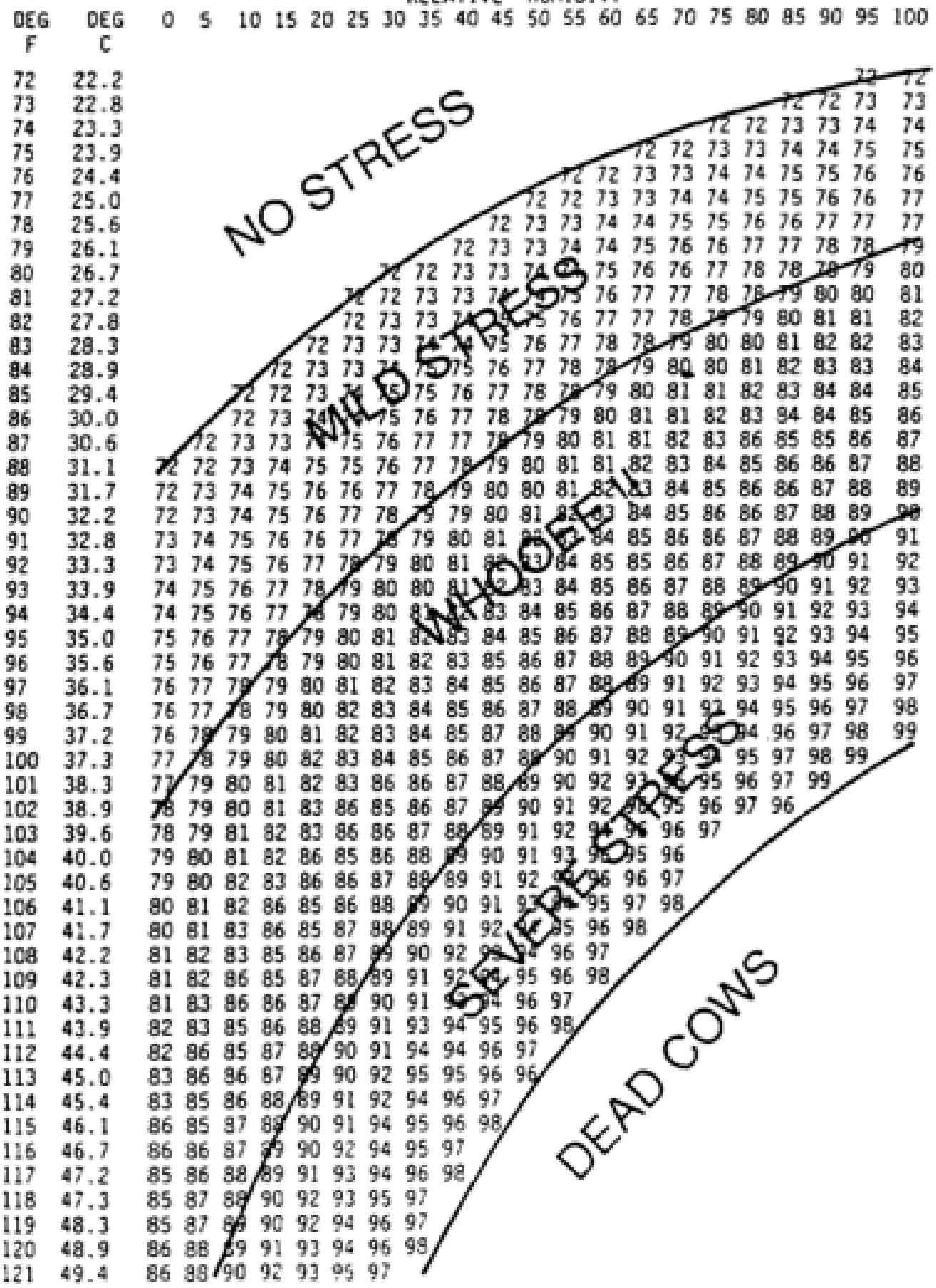

Figure 1.2: Thermal stress zones defined by Armstrong, 1994 


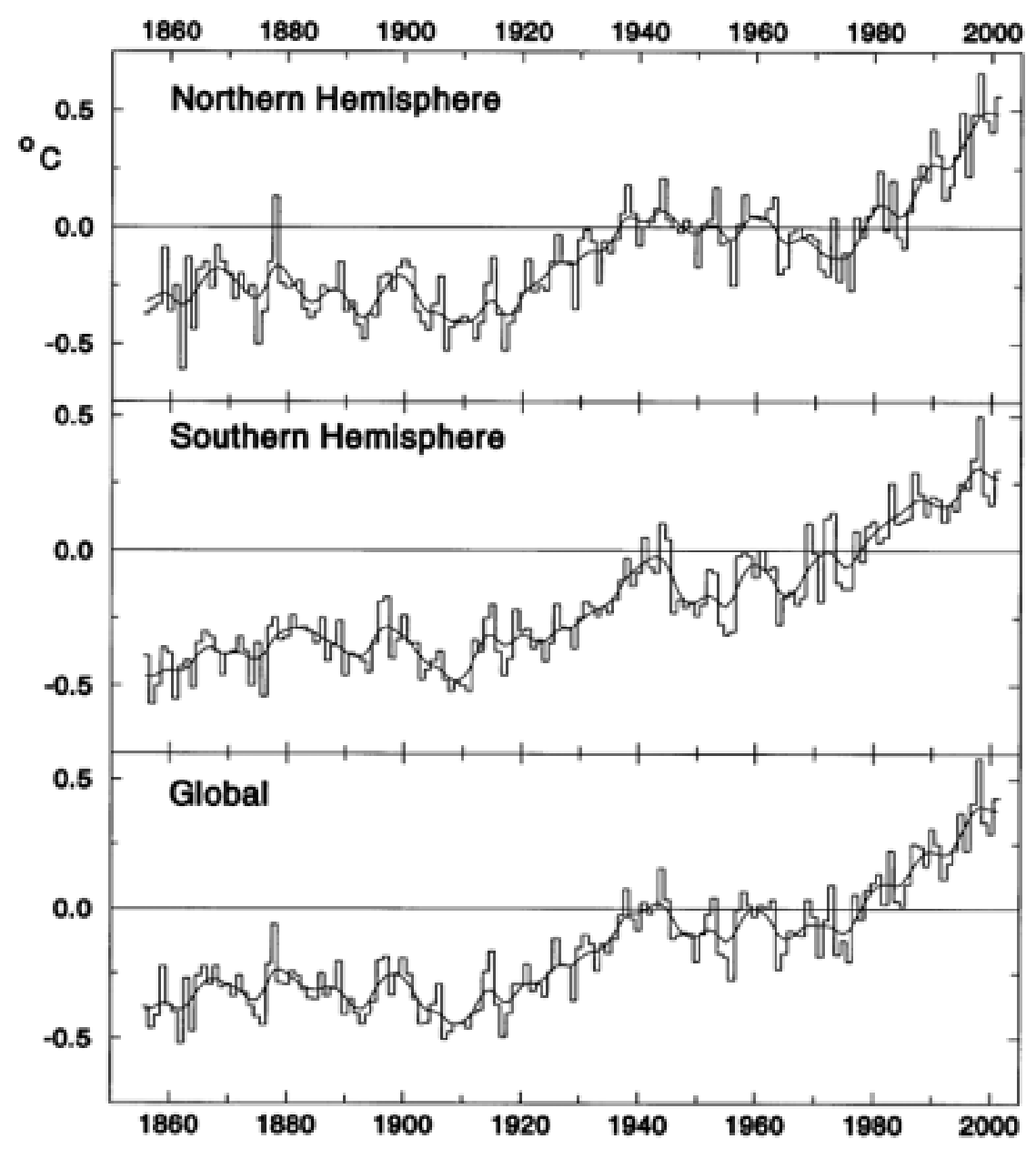

Figure 1.3: Comparison of annual hemispheric and global temperature average for CRUTEM2v, Jones 1994; NCDC: Peterson et al., 1998b; GISS: Hansen et al., 1999, 2001). Taken from Jones and Moberg, 2003 


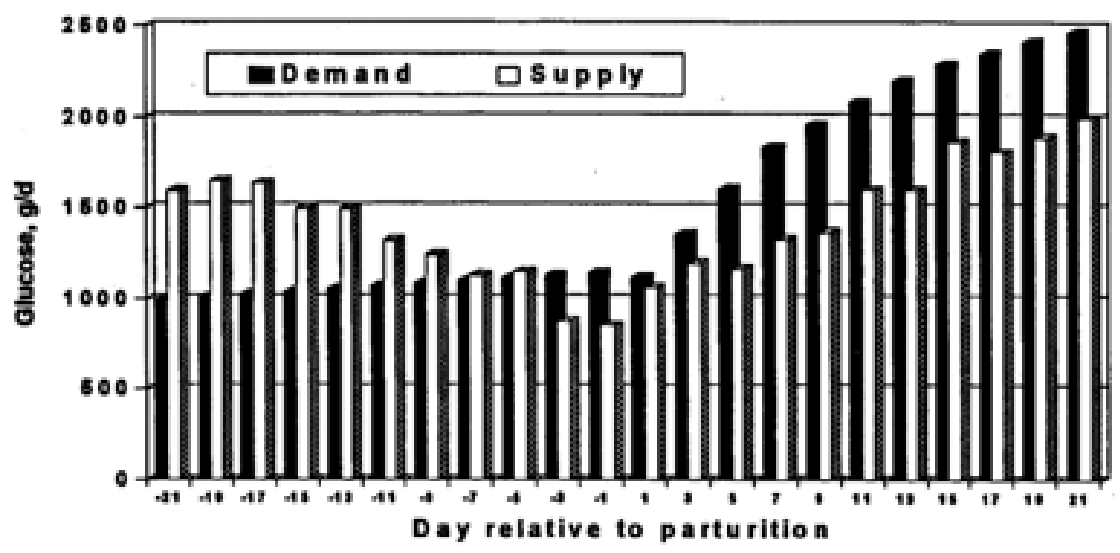

Figure 1.4: Estimated whole-body glucose demand compared with total splanchnic supply of glucose during the periparturient period. (Drackley et al., 2001) 


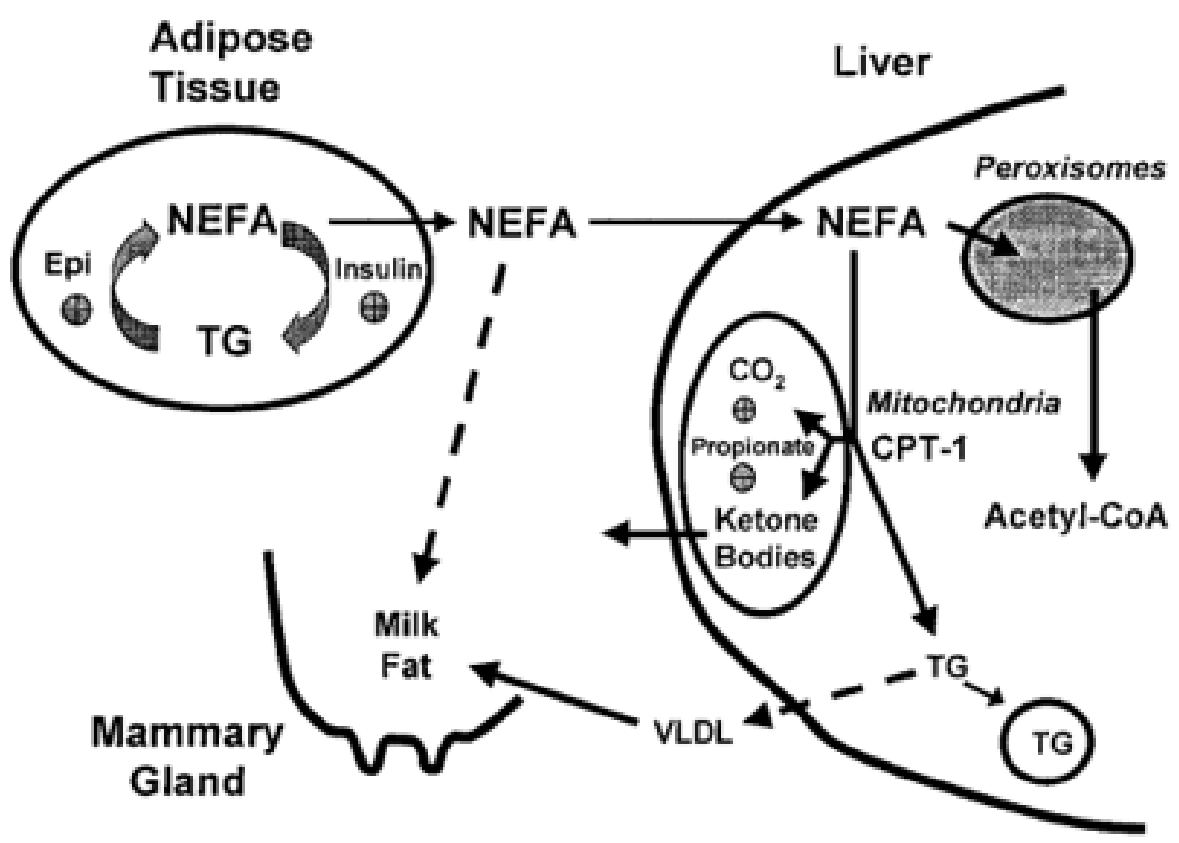

Figure 1.5: Schematic representation of relationships among lipid metabolism in adipose tissue, liver, and mammary gland. Plus signs(+) indicate stimulatory effects, minus signs (-) indicate inhibitory effects. Dashed lines indicate processes that occur at low rates or only during certain physiological states. Abbreviations: epi $=$ epinephrine, $\mathrm{TG}=$ triglyceride, $\mathrm{VLDL}=$ very-low-density lipoproteins, CPT-1 = carnitine palmitoyltransferase 1 (Drackley et al., 2001) 


\section{Chapter 2}

\section{Investigating the effects of a commercial feed additive on production losses during heat stress in mid-lactation Holstein cattle}

\subsection{Introduction}

Heat stress (HS) costs the US approximately $\$ 1$ billion annually (St. Pierre et al., 2003) as a result of decreased milk production and reduction in milk quality, reduced fertility and impaired embryonic development, increased metabolic disease, incidence of health problems (i.e., ruminal acidosis), and cull rates (Collier et al., 1982; West,2003; Jordan, 2003). Heat-stressed cows are in a state of negative energy balance (NEBAL) due to a reduction in dry matter intake (DMI) and an increase in energetically costly heat loss mechanisms (Armstrong, 1994; Moore et al., 2005). Recent studies, however, have demonstrated that the reduction in DMI only accounts for 35 to $50 \%$ of the HS-induced decrease in milk production (Rhoads et al., 2009; Wheelock et al., 2010). This indicates that HS affects milk synthesis through mechanisms independent of reduced nutrient availability. Although HS cows are in NEBAL, their metabolic profile differs from that of cows in lactation-induced NEBAL. Instead of increasing lipolysis and increasing circulating nonesterified fatty acids (NEFA) concentrations to meet energy needs, HS cows 
appear to rely upon glucose as the primary energy substrate (Rhoads et al, 2009; Wheelock et al., 2010; Shwartz et al., 2009). The effects of HS on post-absorptive metabolism appear to be responsible for a significant portion of the reduction in milk yield. However, the mechanisms involved are poorly understood.

There are many nutritional strategies targeting reduced nutrient availability and NEBAL during HS. One such method is to increase the energy content of the diet via the addition of either fat or high-starch grain concentrates. Increasing the energy density of the diet using fat supplements increases milk fat, milk production efficiency, and circulating NEFA, whereas the use of grain concentrates increases milk protein, DMI, and circulating glucose concentrations (Moallem et al., 2010; Drackley et al., 2003). However, regardless of dietary source, increasing dietary energy above $1.75 \mathrm{Mcal} / \mathrm{kg}$ suppresses DMI, indicating that this strategy has limits (Moallem et al., 2010). Additionally, milk fat production is a costly energetic process and increasing milk fat synthesis may further contribute to NEBAL in the HS cow. Suppressing milk fat synthesis through the use of conjugated linoleic acids increases energy availability and promotes a more positive energy balance during HS (Moore et al., 2005). Finally, Shwartz et al. (2009) found that increasing the digestibility of the diet through the use of a yeast culture slightly reduced heat production (likely by decreasing the heat produced during digestion). However, feeding the yeast culture did not prevent the negative effects of HS. Although there are many nutritional strategies designed to target production losses during HS, efficacy varies significantly among products and in individual studies. At present there is no single nutritional strategy that has the ability to prevent decreased milk production, milk quality, and DMI during HS. The aim of the present study was to 
determine the ability of a commercial carbohydrate-based dairy feed additive to mitigate the negative effects of HS on production variables.

\subsection{Materials and Methods}

All procedures involving animals were approved by the University of Missouri Animal Care and Use Committee. Thirty-eight multiparous (parity $=3 \pm 0.2$ ) $(114.4 \pm 2.9 \mathrm{DIM})$ and 10 primiparous $(103.5 \pm 4.8 \mathrm{DIM})$ mid-lactation Holstein cows were blocked according to milk yield, DIM, and parity and then randomly assigned to one of two dietary treatments within block. Treatments were calculated to provide $100 \mathrm{~g}$ (as fed) daily of either sucrose (control; CTL) or a commercial feed additive (Rally ${ }^{\circledR}$, Purina Animal Nutrition, Shoreview, MN; RAL) administered as part of the total mixed ration (TMR). Cows were individually fed the TMR in two daily allotments. Cows were housed at the University of Missouri Foremost Dairy Farm and fed their designated treatment for $21 \mathrm{~d}$ prior to the start of the experiment. Following the initial feeding phase,the trial was composed of two experimental periods consisting of 1) $6.25 \pm 0.3 \mathrm{~d}$ of thermoneutral (TN) conditions and 2) $11.75 \pm 0.3 \mathrm{~d}$ of HS. During the two experimental periods, cows were housed in tie-stalls in the environmental chambers at the University of Missouri's Brody Environmental Center. Each chamber contained six cows, and each two-cow treatment block was assigned to the same chamber.

During period 1 (P1), all animals were housed in constant $\mathrm{TN}$ conditions $\left(20^{\circ} \mathrm{C}\right.$, 48\% humidity (temperature-humidity index, THI =65) with a 16:8 h light:dark

cycle]. Skin temperatures, rectal temperature, and respiratory rate were recorded 
once daily $(1400 \mathrm{~h})$. Skin temperatures were measured in an approximately $5 \mathrm{~cm}^{2}$ shaved area on the ear, shoulder, rump and tail head using a hand-held non-contact infra-red thermometer (Ranger ST ProPlus, Raytek, Santa Cruz, CA). Rectal temperatures were measured with a digital thermometer (Thermistor Model 8110-20, Cole-Parmer Instrument Company, Court Vernon Hills, IL). Respiratory rate (breaths/min) was determined by counting the number of flank movements in 30 sec. Starting on the first day of period 2 (P2) (day 7) and continuing until the last day of the trial (day 18) animals were subjected to cyclical temperatures (designed to mimic ambient daily variation during the summer months) ranging from 23.8 to $30.2^{\circ} \mathrm{C}$ with THI ranging from 69.3 to 75.5 and a $16: 8 \mathrm{~h}$ light:dark cycle. Skin temperatures, rectal temperature, and respiratory rate were measured four times daily $(0000,0500,1400$, and $1700 \mathrm{~h})$ during P2. If at any point during P2 the rectal temperature of individual animals exceeded $40.5^{\circ} \mathrm{C}$, these individual animals were cooled to $<40.5^{\circ} \mathrm{C}$ using evaporative cooling (fans plus water).

During both experimental periods, cows were fed for ad libitum intake and the TMR was formulated to meet or exceed NRC requirements under thermoneutral conditions (NRC, 2001). All animals were individually fed a TMR twice daily (0500 and $1700 \mathrm{~h}$ ). Orts were recorded at the PM feeding during P1 and at the AM and PM feedings during P2. Corn silage was the primary forage and ground corn was the primary concentrate (Tables 2.1 and 2.2). The TMR was sampled weekly and analyzed by wet chemistry methods (DairyOne Cooperative Inc, Ithaca, NY) for nutrient composition (Table 2.1). Average body condition scores (assessed by two independent observers) were recorded weekly.

Cows were milked twice daily (0600 and $1800 \mathrm{~h}$ ) and milk yields were recorded 
on each occasion. Milk samples were collected from each cow (from two consecutive milkings) on days $3,6,10,14$, and 18 of the overall experimental period. Samples were stored at room temperature with a preservative until analysis by Mid-South Dairy Records (Springfield, MO) for milk components [fat, protein, and somatic cell score (SCS)]. Blood samples were collected following the morning milking (approximately 3 hours post-feeding) via coccygeal venipuncture on days $3,7,10$, 14, and 18. Blood samples were then centrifuged at $1,500 \mathrm{x} \mathrm{g}$ for $15 \mathrm{~min}$ at $4^{\circ} \mathrm{C}$, and the plasma was harvested, divided into three aliquots and frozen at $-20^{\circ} \mathrm{C}$. Plasma $\beta$-hydroxybutyrate (BHBA), NEFA, and glucose were measured enzymatically using commercially available kits validated in our laboratory. Insulin was measured via a commercially available ELISA kit (Mercodia AB, Uppsala, Sweeden). Plasma cortisol concentrations were measured using a radio-immunoassay kit (Corti-Cote Cortisol Antibody Coated Tube- 125I RIA kit MP Biomedicals Solon, OH).

\subsubsection{Calculations}

Energy-corrected milk (ECM) was calculated using the equation: ECM = $[\operatorname{milk}(\mathrm{kg} / \mathrm{d}) \times 0.327]+[\operatorname{fat}(\mathrm{kg} / \mathrm{d}) \times 12.86]+[\operatorname{protein}(\mathrm{kg} / \mathrm{d}) \times \mathrm{x}$ 7.65]. Fat-corrected milk (FCM) was calculated using the equation:3.5\% FCM $=(0.432 \mathrm{x} \mathrm{kg} \mathrm{milk)}+$ (16.22 x kg fat). Feed efficiency was calculated using ECM and 3.5\% FCM (Feed efficiency $=\mathrm{ECM} / \mathrm{DMI})$. 


\subsubsection{Statistical Analysis}

All variables were analyzed by analysis of variance using the Mixed procedure of SAS (SAS Institute Inc., Cary, NC) in which the fixed effect was temperature and treatment and block were random effects. Each block was analyzed with repeated measures with either a compound symmetry or autoregressive (1) covariance structure and time was the repeated effect (Littell et al., 1998). Degrees of freedom were adjusted using the kenward-roger approximation. Pre-treatment covariates, when significant, were used for all variables except skin temperatures and respiratory rates.

\subsection{Results and Discussion}

Thermal stress markedly changes the physiology and metabolism of lactating dairy cows, ultimately resulting in decreased milk production. During P1, all cows were maintained under thermal neutral conditions $\left(20^{\circ} \mathrm{C}, 48 \%\right.$ humidity, $\left.\mathrm{THI}=65\right)$ and as was expected, there were no treatment effects on any of the measured variables (data not shown). Our study utilized a heat stress model in which cyclical daily temperatures ranged between 23.8 to $30.2^{\circ} \mathrm{C}$ (Figure 2.1 ). In this model ambient temperatures were not as severe as in other climate controlled studies in which the cyclical daily temperatures ranged between 29.4 and $39.2^{\circ} \mathrm{C}$ (Rhoads et al., 2009; Wheelock et al., 2010). These studies designed their heat stress model to mimic a typical summer day in Arizona, an arid state where the mean ambient temperature during July is $35^{\circ} \mathrm{C}$ and relative humidity $(\mathrm{RH})<30 \%$ (Bohmanova et 
al., 2007). In contrast to Arizona, Missouri is climatically similar to that Southeastern states such as Georgia, which are characterized by high humidity and less extreme mean temperatures during July. As such, cattle in Missouri face an increased humidity load and lower ambient temperature compared to their Arizonan counterparts. Although the mean daily temperature did not exceed $30.2^{\circ} \mathrm{C}$ during P2, rectal temperature increased from 38.9 to $40.0^{\circ} \mathrm{C}$ and respiratory rate increased from 61 to 81 breaths/min from P1 to P2 $(P<0.01$; Table 2.4). These increases in rectal temperature and respiratory rate indicate that the cattle in our study were experiencing thermal stress despite the use of a less severe HS model (Table 2.4). Surface skin temperature also increased from P1 to P2 $(P<0.01$; Table 2.4). Interestingly RAL treated cows had lower rump skin temperature during P2 than CTL cows (37.9 vs. $38.2^{\circ} \mathrm{C} ; P=0.02$; Table 2.3$)$, however there were no treatment effects on ear, shoulder, and tail head skin temperatures, rectal temperature, or respiratory rate during $\mathrm{P} 2$.

Daily milk yield decreased $5.9 \mathrm{~kg}$ from P1 to P2 (Day effect, $P<0.01$; Table 2.4) and a treatment by day interaction was observed for milk yield as milk yield was greater in RAL cows during P2 $(P=0.05$; Figure 2.3$)$. Compared to the control, RAL treatment had no overall effect on milk yield in P2 (Table 2.3). Cattle in our study did not experience as precipitous decline in milk yield as reported in other HS studies. For example, in our study milk production decreased by approximately $15 \%$ (15.5\% in CTL cows vs. $14.02 \%$ in RAL cows; $P=0.20)$ whereas milk production decreased by $33 \%$ as a result of thermal stress in the report by Shwartz et al. (2009). This may in part be due to the less severe HS model used in our study and the increased milk yield over time seen in RAL cows. $(P=0.47)$. Daily DMI 
decreased $4.7 \mathrm{~kg}$ (Day effect, $P<0.01$ ) from P1 to P2 (Table 2.4); however, an $18 \%$ decrease in DMI was not as severe as seen in other reports where thermal stress decreased DMI 28\% (Wheelock et al., 2010; Shwartz et al., 2009; Rhoads et al., 2009). A treatment by day interaction was observed for DMI during P2 as DMI was greater in RAL cows over time $(P=0.05 ;$ Figure 2.2$)$. However, there was no overall effect of RAL treatment on DMI (Table 2.3). CTL cows experienced an an 18\% decline in DMI from P1 to P2 and RAL cows experienced an $18.5 \%$ decline in DMI from $\mathrm{P} 1$ to $\mathrm{P} 2(P=0.68)$.

Milk fat percentage was not affected by period $(P>0.1$; Table 2.4$)$. However RAL treated cows tended to have $2.7 \%$ lower milk fat percentage during P2 than the CTL cows (Figure 2.5; $P=0.07$ ). There was no effect of treatment on milk fat yield during P2 (Table 2.3). Shwartz et al. (2009) and Rhoads et al. (2009) report that cattle experiencing climate-controlled HS conditions do not experience the typical milk fat depression seen during summer months on commercial dairies, which is in agreement with our findings. Although there was no effect of period on milk fat percent, milk fat yield decreased from P1 to P2 (1.44 vs. $1.21 \mathrm{~kg} / \mathrm{d}$; Day effect, $P<0.01$ ). Milk protein yield and protein percent decreased (Day effect, $P<$ $0.01)$ from $\mathrm{P} 1$ to $\mathrm{P} 2(1.16$ vs. $0.92 \mathrm{~kg} / \mathrm{d} ; 2.88$ vs. $2.73 \%)$. The decrease in milk fat yield and protein yield as a result of HS is in agreement with other lactating dairy cattle HS studies (Bandaranayaka and Holmes, 1976; Ravagnolo and Misztal, 2000). In agreement with other climate-controlled HS studies, ECM and 3.5\% FCM decreased $(P<0.01)$ as the cows transitioned from thermoneutral to heat stress conditions (Table 2.4; Shwartz et al., 2009). In our study ECM decreased from 40.7 to $33.7 \mathrm{~kg} / \mathrm{d}$ and $3.5 \%$ FCM decreased from 40.8 to $34.1 \mathrm{~kg} / \mathrm{d}$ from P1 to P2 (Day 
effect, $P<0.01$ ). This represents a $\sim 17 \%$ decrease in the energy content of the milk. There was no effect of treatment during P2 on either ECM or 3.5\% FCM (Table 2.3). In contrast to other reports, feed efficiency (as measured by ECM and 3.5\% FCM) increased from P1 to P2 (Table 2.4; McDowell et al., 1969). Finally, RAL treatment increased both ECM and 3.5\% FCM feed efficiency compared to control cows during P2 (Table 2.3; Figures 2.6 and 2.7).

The plasma glucose concentration decreased from P1 to P2 (68.6 vs. $64.6 \mathrm{mg} / \mathrm{dL}$; Day effect, $P<0.01$ ), but was unaffected by RAL treatment during P2 (Table 2.3). This observation is consistent with the reported decrease in plasma glucose concentration during HS (Baumgard et al., 2007). Unlike cows in lactation-induced NEBAL where glucose disposal is decreased, heat-stressed cows have increased glucose disposal during periods of NEBAL (Wheelock et al., 2010). Due to the limitations of our study it unknown whether the decrease in plasma glucose was a result of impaired hepatic function or an increased rate of disposal. In addition to increased glucose disposal rates, plasma NEFA concentrations do not increase in cows in NEBAL resulting from HS (Rhoads et al., 2009; Wheelock et al., 2010; Shwartz et al., 2009). This is interesting as plasma NEFA concentrations increased dramatically in cows experiencing lactation-induced NEBAL (Rhoads et al., 2009). In our study rather than remain constant, NEFA concentrations actually decreased from P1 to P2 (160.4 vs $129.4 \mu \mathrm{Eq} / \mathrm{L}$; Day effect, $P<0.01)$. Decreased overall NEFA from P1 to P2 may be due to the fact that RAL treated cows tended to have lower total NEFA levels (156.2 vs. $188.8 \mu \mathrm{Eq} / \mathrm{L} ; P=0.09)$ during P2 than CTL cows (Figure 2.4). Although total NEFA concentration tended to be lower in RAL cows in P2, this did not translate to a decreased loss of body condition compared to 
CTL cows (3.11 vs. 3.14; Table 2.3). Body condition score did decrease from P1 to P2 (3.31 vs. 3.12; Day effect, $P<0.01)$ but there was no effect of RAL treatment during P2.

HS increases the circulating levels of cortisol, epinephrine, and norepinephrine, hormones that typically increase lipolysis and NEFA mobilization (Beede and Collier, 1986); however, both basal and peak insulin levels increase during HS (Wheelock et al., 2010). In our study the plasma insulin concentration increased from 0.74 to $0.86 \mathrm{ng} / \mathrm{mL}$ from $\mathrm{P} 1$ to $\mathrm{P} 2$, but was unaffected by RAL treatment (Table 2.3). This increased insulin concentration is in agreement with Shwartz et al. (2009) and may help explain the lack of NEFA response during HS. Cortisol levels typically increase during periods of thermal stress (Beede and Collier, 1986), however in our study we observed a decrease in plasma cortisol from P1 to P2 (Table 2.4). It is unclear why plasma cortisol concentrations were lower during HS than TN. The timing of blood sampling of cortisol my have precluded detection of elevated cortisol levels in the current study. Blood samples were obtained early in the day after exposure to cooler nighttime THI. Potentially elevated cortisol levels may have decreased by sampling time due to this period of relative thermoneutrality.

\subsection{Conclusion}

Identifying nutritional strategies that decrease production losses during heat stress is of paramount importance to the dairy industry. The current study suggests that the addition of the commercial feed additive Rally ${ }^{\circledR}$ to the diet of mid-lactation dairy cattle experiencing acute heat stress increases milk yield and DMI during heat 
stress. This feed additive also appears to facilitate a more favorable energy balance as evidenced by decreased plasma NEFA and increased DMI. Further experiments are warranted to identify the mechanism(s) by which Rally ${ }^{\circledR}$ supplementation decreases the negative effects of heat stress on lactating dairy cattle. Finally, additional research is required to examine the effects of Rally ${ }^{\circledR}$ supplementation on lactating dairy cattle experiencing a longer period of heat stress.

\subsection{Acknowledgments}

The authors express their appreciation to Land O' Lakes Purina Feed for funding this experiment. 


\subsection{Tables for Chapter 2}

Table 2.1: Ingredients and chemical composition of the total mixed ration (TMR) diet fed during the study (on a dry matter basis). The TMR was sampled weekly and analyzed by wet chemistry methods for nutrient composition (DairyOne Cooperative Inc., Ithaca, NY).

\begin{tabular}{|c|c|}
\hline \multicolumn{2}{|l|}{ Component } \\
\hline Corn silage, $\%$ & 33.8 \\
\hline Alfalfa haylage, $\%$ & 10.5 \\
\hline Alfalfa hay $\%$ & 5.7 \\
\hline Ground corn, \% & 18.9 \\
\hline Brewers grain, \% & 7.8 \\
\hline Ground soybean hulls, \% & 6.0 \\
\hline Vitamins \& Minerals Mix, \% & 17.3 \\
\hline $\mathrm{DM}^{1}, \%$ & 92.3 \\
\hline $\mathrm{CP}^{2}, \%$ & 18.8 \\
\hline Available protein, $\%$ of $\mathrm{CP}$ & 17.6 \\
\hline $\mathrm{NDF}^{3}, \%$ & 32.1 \\
\hline $\mathrm{ADF}^{4}, \%$ & 22.4 \\
\hline Lignin, \% & 4.3 \\
\hline $\mathrm{NFC}^{5}, \%$ & 39.0 \\
\hline Starch, \% & 21.8 \\
\hline Crude fat, \% & 5.2 \\
\hline Ash, \% & 8.6 \\
\hline $\mathrm{NEL}^{6}, \mathrm{Mcal} / \mathrm{kg}$ of DM & 0.8 \\
\hline \multicolumn{2}{|l|}{ Mineral content } \\
\hline $\mathrm{Ca}, \%$ & 1.2 \\
\hline $\mathrm{P}, \%$ & 0.4 \\
\hline $\mathrm{Mg}, \%$ & 0.4 \\
\hline $\mathrm{K}, \%$ & 1.6 \\
\hline $\mathrm{Na}, \%$ & 0.5 \\
\hline $\mathrm{Fe}, \mathrm{ppm}$ & 390.8 \\
\hline $\mathrm{Zn}, \mathrm{ppm}$ & 121.3 \\
\hline $\mathrm{Cu}, \mathrm{ppm}$ & 35.4 \\
\hline $\mathrm{Mn}, \mathrm{ppm}$ & 89.6 \\
\hline Mo, ppm & 0.9 \\
\hline S, $\%$ & 0.4 \\
\hline $\mathrm{Cl}, \%$ & 0.4 \\
\hline $\mathrm{DCAD}^{7}, \mathrm{mEq} / 100 \mathrm{~g}$ & 28.6 \\
\hline
\end{tabular}


${ }^{1}$ Dry matter

${ }^{2}$ Crude protein

3 Neutral detergent fiber

4 Acid detergent fiber

${ }^{5}$ Non-fermentable carbohydrates

6 Net energy of lactation

7 Dietary cation-anion difference 
Table 2.2: Composition of the vitamins and minerals mix from Table 2.1. Ingredients are expressed as a percent of the total dry matter of the mix.

\begin{tabular}{ll}
\hline Ingredient & \% of total $\mathrm{DM}^{1}$ \\
\hline Soybean meal 47.5 solvent & 29.9 \\
Amino plus & 21.8 \\
Control or Rally ${ }^{\circledR}$ treatment & 9.9 \\
Blood meal & 7.6 \\
Energy booster & 8.2 \\
Limestone ground & 6.5 \\
Sodium bicarbonate & 5.4 \\
Dynamate & 2.2 \\
Potassium carbonate & 2.2 \\
Salt white & 1.4 \\
Magnesium oxide & 1.3 \\
Trace mineral mix & 1.2 \\
Vitamin E & 1.1 \\
Meta smart dry & 1.0 \\
Vitamin A, D, E & 0.3 \\
\hline
\end{tabular}

${ }^{1}$ Dry matter 
Table 2.3: Effects of RAL treatment on production variables, plasma metabolites, and body temperature during $\mathrm{P} 2^{1}$. Treatments were $100 \mathrm{~g}$ daily (as fed) of either sucrose (CTL) or Rally ${ }^{\circledR}$ (RAL) mixed into the ration. P2 was the heat stress portion of the experiment beginning on day 7 and continuing until the last day of the trial (day 18). During P2 animals were housed in environmental chambers and subjected to cyclical temperatures (designed to mimic ambient daily variation during the summer months) ranging from 23.8 to $30.2^{\circ} \mathrm{C}$, with the temperature humidity index ranging from 69.3 to 75.5 .

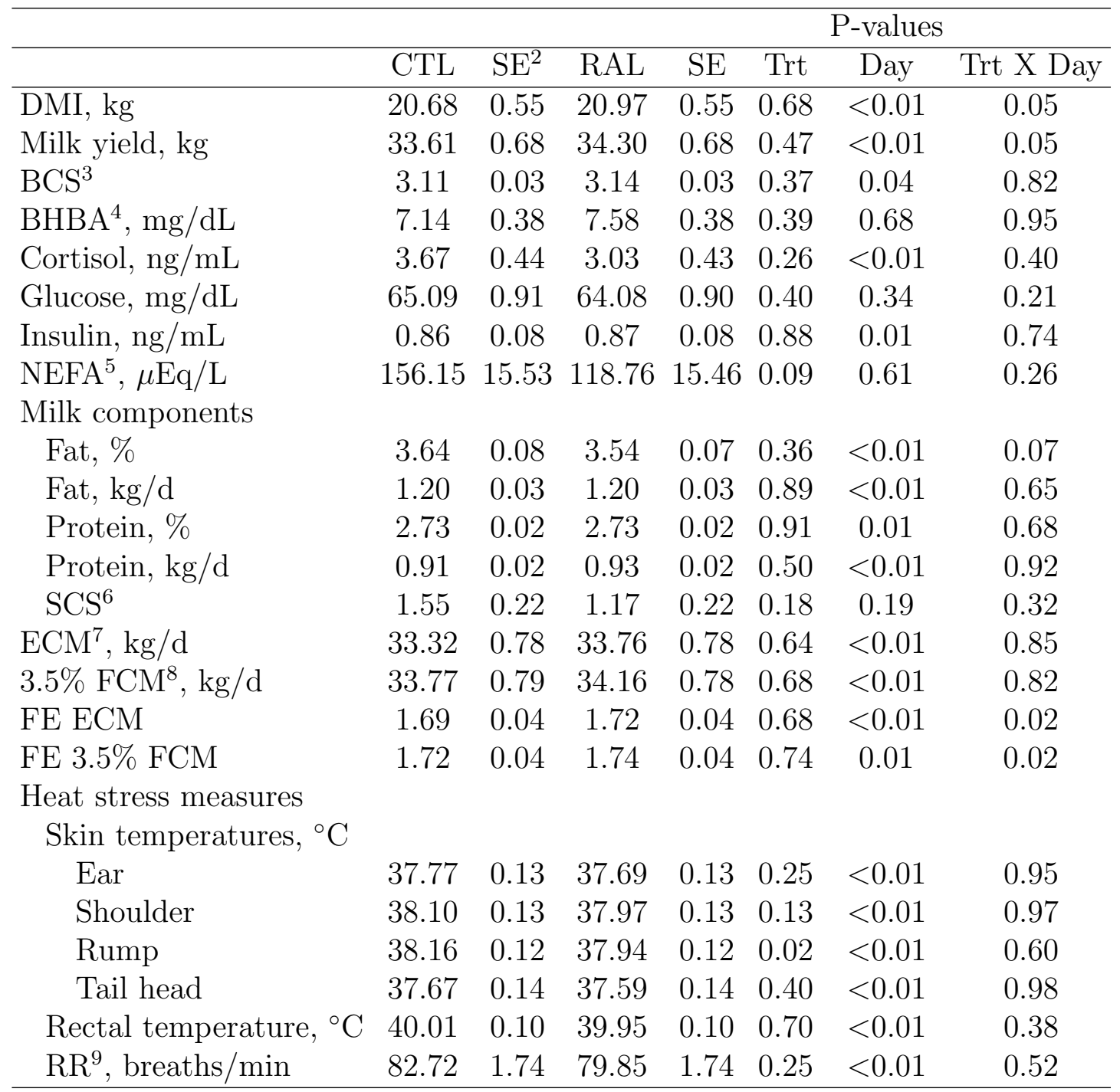

${ }^{1}$ Data in this table represent the least square means and standard errors from P2 ${ }^{2}$ Standard error of the mean 
${ }^{3}$ Body condition score

${ }^{4} \beta$-hydroxybutyrate

${ }^{5}$ Nonesterified fatty acids

${ }^{6}$ Somatic cell score

${ }^{7}$ Energy-corrected milk

${ }^{8}$ Fat-corrected milk

${ }^{9}$ Respiratory rate 
Table 2.4: Production variables, plasma metabolites, and body temperature during $\mathrm{P} 1$ (thermoneutral) and $\mathrm{P} 2^{1}$. P1 was the thermoneutral portion of the experiment and from days 1 to 6 animals were maintained under thermoneutral conditions $\left(20^{\circ} \mathrm{C}, 48 \%\right.$ humidity, temperature-humidity index $=65)$. $\mathrm{P} 2$ was the heat stress portion of the experiment beginning on day 7 and continuing until the last day of the trial (day 18). During P2 animals were were housed in environmental chambers and subjected to cyclical ambient temperatures (designed to mimic ambient daily variation during the summer months) ranging from 23.8 to $30.2^{\circ} \mathrm{C}$, with the temperature humidity index ranging from 69.3 to 75.5 .

\begin{tabular}{|c|c|c|c|c|c|}
\hline & P1 & $\mathrm{SE}^{2}$ & P2 & SE & $\mathrm{P}$-value \\
\hline DMI, kg & 25.51 & 0.39 & 20.85 & 0.37 & $<0.01$ \\
\hline Milk yield, $\mathrm{kg}$ & 39.90 & 0.41 & 34.00 & 0.38 & $<0.01$ \\
\hline $\mathrm{BCS}^{3}$ & 3.31 & 0.02 & 3.12 & 0.02 & $<0.01$ \\
\hline $\mathrm{BHBA}^{4}, \mathrm{mg} / \mathrm{dL}$ & 6.75 & 0.28 & 7.37 & 0.25 & 0.05 \\
\hline Cortisol, ng/mL & 4.80 & 0.49 & 3.32 & 0.42 & 0.01 \\
\hline Glucose, $\mathrm{mg} / \mathrm{dL}$ & 68.59 & 0.78 & 64.56 & 0.70 & $<0.01$ \\
\hline Insulin, ng/mL & 0.74 & 0.07 & 0.86 & 0.05 & 0.06 \\
\hline $\mathrm{NEFA}^{5}, \mathrm{mEq} / \mathrm{L}$ & 160.38 & 6.65 & 129.42 & 5.77 & $<0.01$ \\
\hline \multicolumn{6}{|l|}{ Milk components } \\
\hline Fat, \% & 3.59 & 0.17 & 3.60 & 0.16 & 0.82 \\
\hline Fat, kg/d & 1.44 & 0.03 & 1.21 & 0.03 & $<0.01$ \\
\hline Protein, \% & 2.88 & 0.02 & 2.73 & 0.02 & $<0.01$ \\
\hline Protein, $\mathrm{kg} / \mathrm{d}$ & 1.16 & 0.02 & 0.92 & 0.01 & $<0.01$ \\
\hline $\mathrm{SCS}^{6}$ & 1.29 & 0.15 & 1.30 & 0.14 & 0.92 \\
\hline $\mathrm{ECM}^{7}, \mathrm{~kg} / \mathrm{d}$ & 40.74 & 0.59 & 33.70 & 0.57 & $<0.01$ \\
\hline $3.5 \% \mathrm{FCM}^{8}, \mathrm{~kg} / \mathrm{d}$ & 40.82 & 0.63 & 34.14 & 0.60 & $<0.01$ \\
\hline FE ECM & 1.59 & 0.02 & 1.70 & 0.02 & $<0.01$ \\
\hline FE $3.5 \%$ FCM & 1.60 & 0.02 & 1.73 & 0.03 & $<0.01$ \\
\hline \multicolumn{6}{|l|}{ Heat stress measures } \\
\hline \multicolumn{6}{|l|}{ Skin temperatures, ${ }^{\circ} \mathrm{C}$} \\
\hline Ear & 36.69 & 0.13 & 37.73 & 0.12 & $<0.01$ \\
\hline Shoulder & 36.86 & 0.13 & 38.04 & 0.12 & $<0.01$ \\
\hline Rump & 36.78 & 0.12 & 38.05 & 0.12 & $<0.01$ \\
\hline Tail head & 36.34 & 0.15 & 37.64 & 0.14 & $<0.01$ \\
\hline Rectal temperatur & 38.88 & 0.07 & 39.98 & 0.07 & $<0.01$ \\
\hline $\mathrm{RR}^{9}$, breaths/min & 60.69 & 2.49 & 81.41 & 2.35 & $<0.01$ \\
\hline
\end{tabular}

${ }^{1}$ Data in this table represent the least square means and standard errors from $\mathrm{P} 1$ and $\mathrm{P} 2$ 
${ }^{2}$ Standard error of the mean

${ }^{3}$ Body condition score

${ }^{4} \beta$-hydroxybutyrate

${ }^{5}$ Nonesterified fatty acids

${ }^{6}$ Somatic cell score

${ }^{7}$ Energy-corrected milk

${ }^{8}$ Fat-corrected milk

${ }^{9}$ Respiratory rate 


\section{7 $\quad$ Figures for Chapter 2}

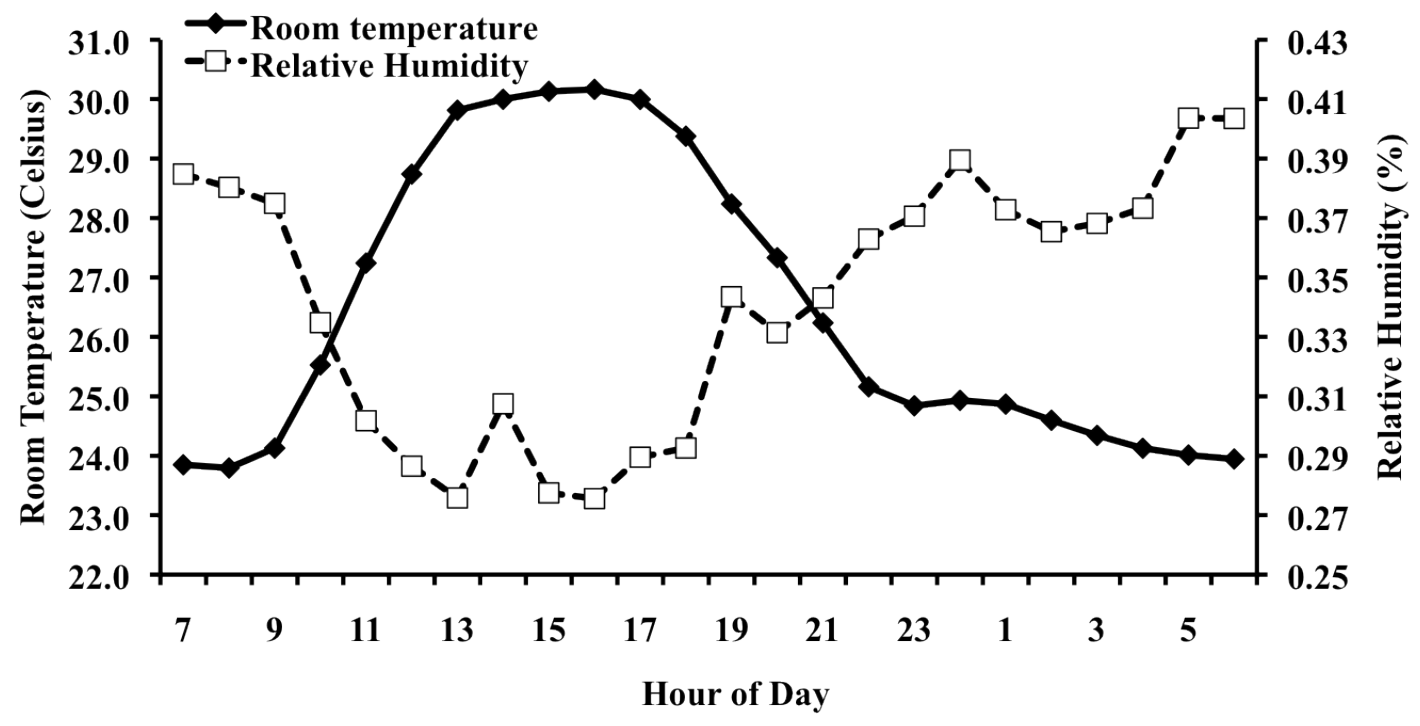

Figure 2.1: Average hourly temperature and relative humidity during P2. P2 was the heat stress portion of the experiment, beginning on day 7 and continuing until the last day of the trial (day 18). During P2 animals were were housed in environmental chambers and subjected to cyclical temperatures (designed to mimic ambient daily variation during the summer months) ranging from 23.8 to $30.2^{\circ} \mathrm{C}$, with the temperature humidity index ranging from 69.3 to 75.5 . 


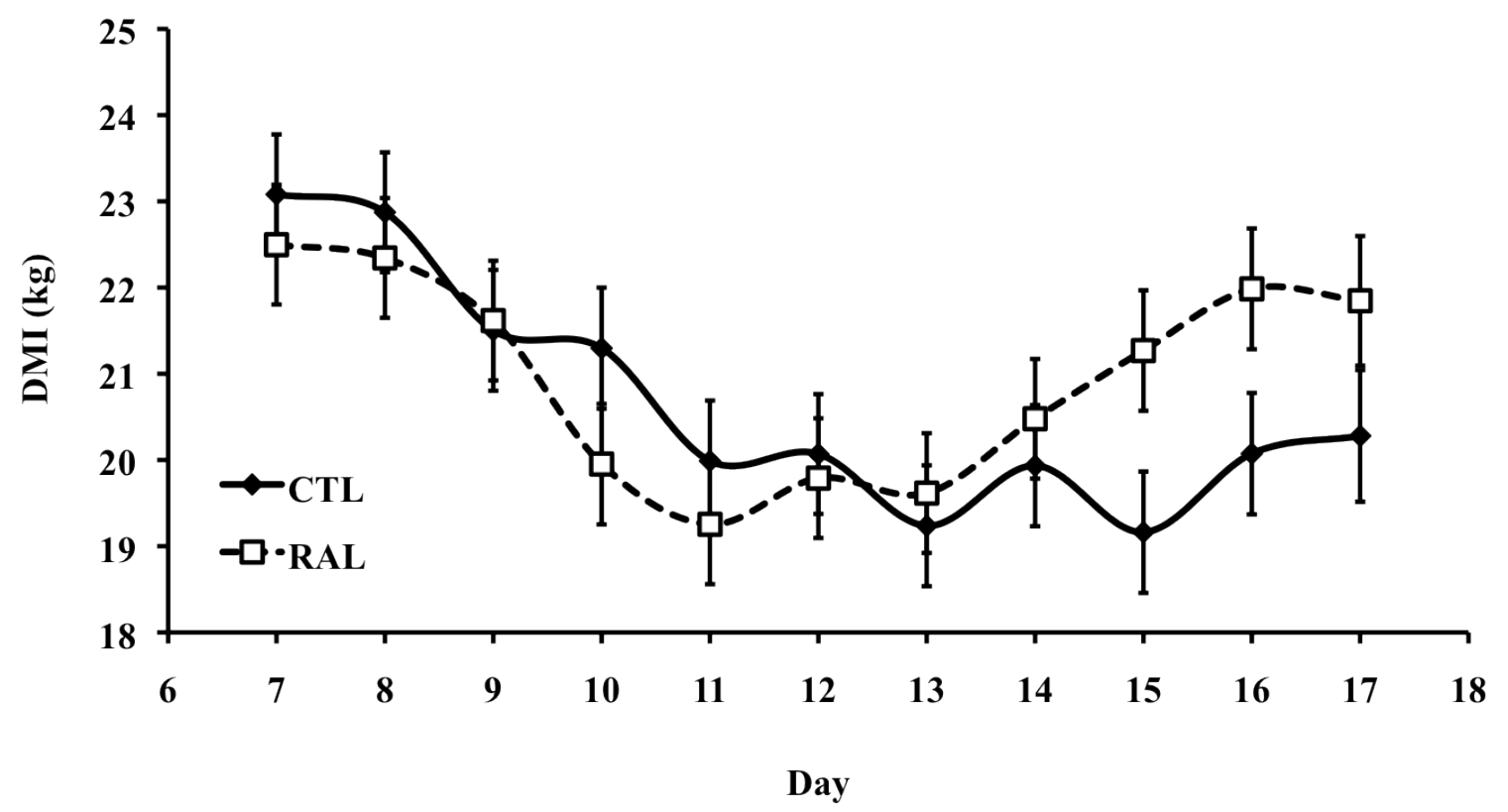

Figure 2.2: The effects of RAL treatment on dry matter intake (DMI) for CTL and RAL cows during P2. Treatments were $100 \mathrm{~g}$ daily (as fed) of either sucrose (CTL) or Rally ${ }^{\circledR}$ (RAL) mixed into the ration. P2 was the heat stress portion of the experiment beginning on day 7 and continuing until the last day of the trial (day 18). During P2 animals were subjected to cyclical temperatures (designed to mimic ambient daily variation during the summer months) ranging from 23.8 to $30.2^{\circ} \mathrm{C}$, with the temperature humidity index ranging from 69.3 to 75.5 . Days marked with a ${ }^{*}$ designate significance at $P<0.05$. There was a significant treatment by day interaction $(P=0.05)$; however, there were no treatment effects. 


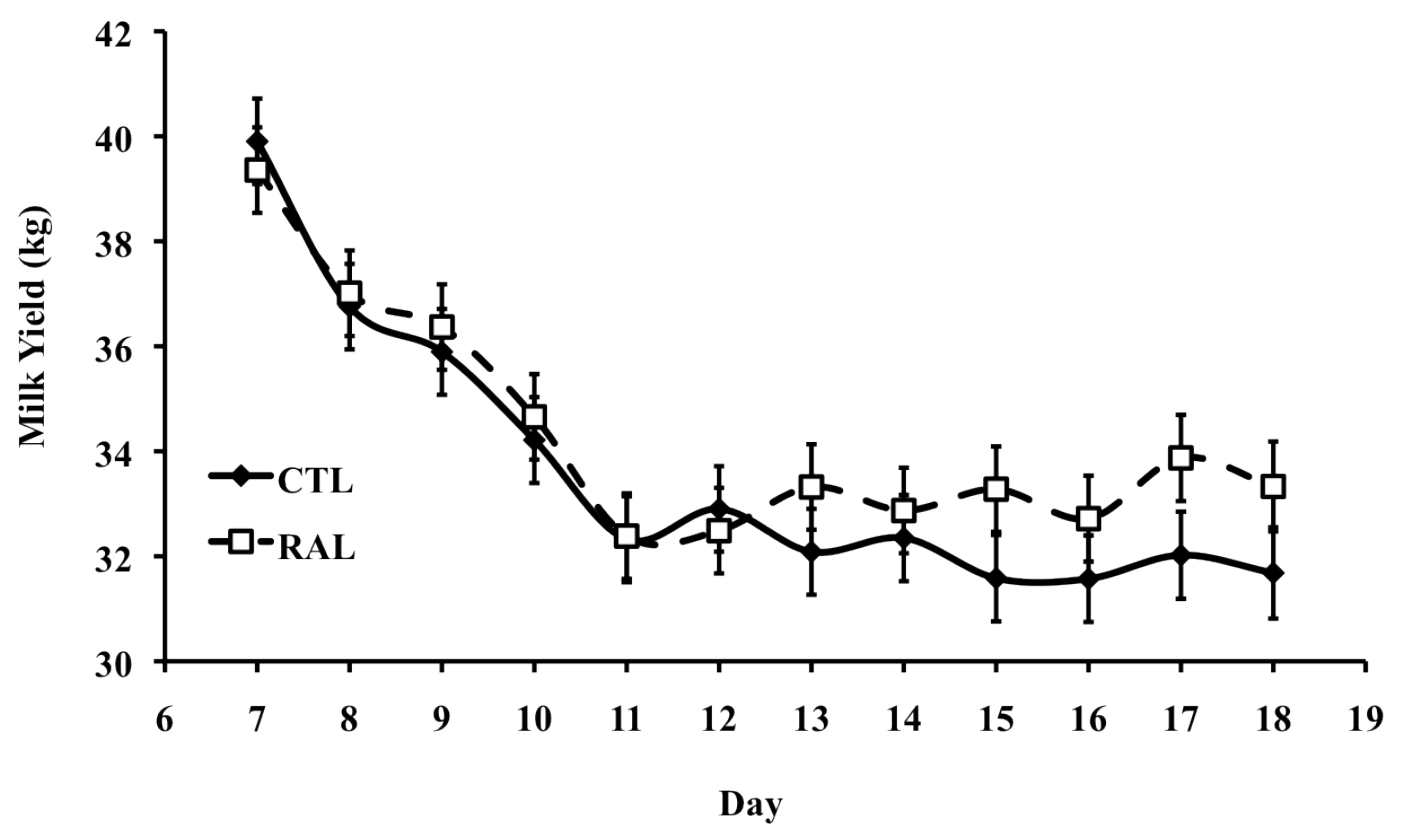

Figure 2.3: The effects of RAL treatment on milk yield for CTL and RAL cows during P2. Treatments were $100 \mathrm{~g}$ daily (as fed) of either sucrose (CTL) or Rally ${ }^{\circledR}$ (RAL) mixed into the ration. P2 was the heat stress portion of the experiment beginning on day 7 and continuing until the last day of the trial (day 18). During P2 animals were were housed in environmental chambers and subjected to cyclical temperatures (designed to mimic ambient daily variation during the summer months) ranging from 23.8 to $30.2^{\circ} \mathrm{C}$, with the temperature humidity index ranging from 69.3 to 75.5 No significant treatment effect was detected, however there was a significant treatment by day interaction $(P=0.05)$ 


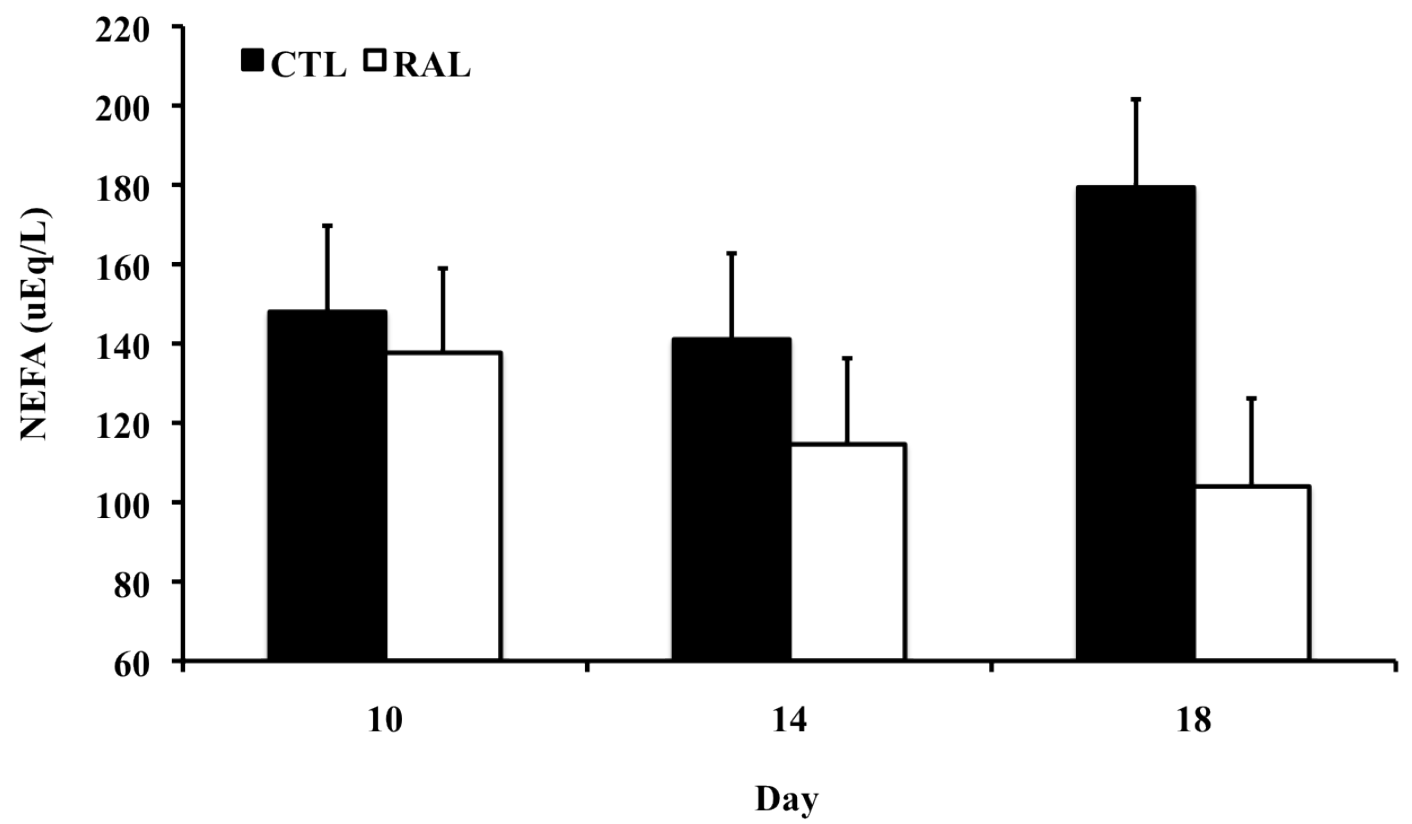

Figure 2.4: The effects of RAL treatment on plasma nonesterified fatty acid (NEFA) concentrations for CTL and RAL cows during P2. Treatments were $100 \mathrm{~g}$ daily (as fed) of either sucrose (CTL) or Rally ${ }^{\circledR}$ (RAL) mixed into the ration. P2 was the heat stress portion of the experiment beginning on day 7 and continuing until the last day of the trial (day 18). During P2 animals were were housed in environmental chambers and subjected to cyclical temperatures (designed to mimic ambient daily variation during the summer months) ranging from 23.8 to $30.2^{\circ} \mathrm{C}$, with the temperature humidity index ranging from 69.3 to 75.5 Blood samples were collected following the morning milking on days 10, 14, and 18 and to assess plasma NEFA concentrations. RAL treatment tended to decrease plasma NEFA $(P=0.09)$, however there was no treatment by day interaction. 


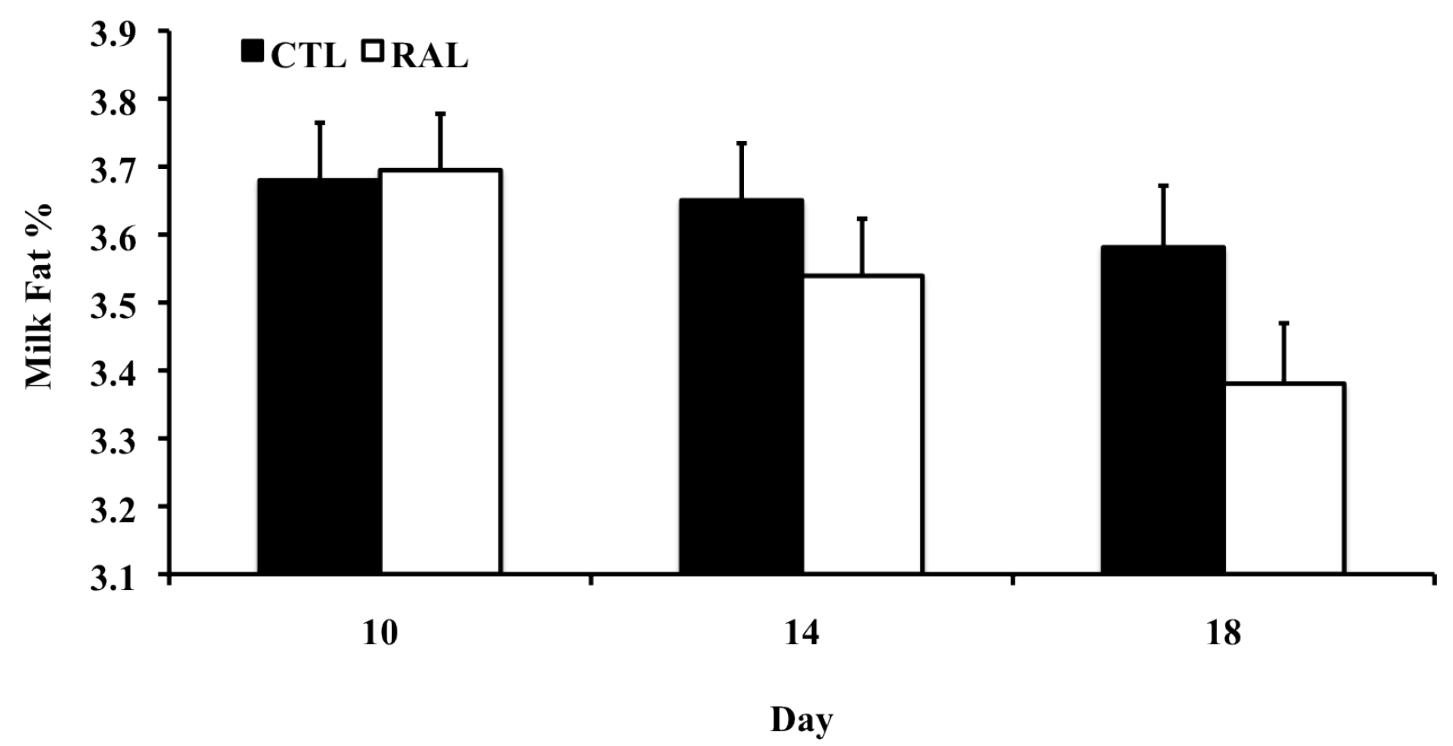

Figure 2.5: The effects of RAL treatment on milk fat percentage. Treatments were $100 \mathrm{~g}$ daily (as fed) of either sucrose (CTL) or Rally ${ }^{\circledR}$ (RAL) mixed into the ration. $\mathrm{P} 2$ was the heat stress portion of the experiment beginning on day 7 and continuing until the last day of the trial (day 18). During P2 animals were were housed in environmental chambers and subjected to cyclical temperatures (designed to mimic ambient daily variation during the summer months) ranging from 23.8 to $30.2^{\circ} \mathrm{C}$, with the temperature humidity index ranging from 69.3 to 75.5. Milk samples were taken from 2 consecutive milkings on days 10, 14, and 18 of the experimental period and assessed for milk fat content.. RAL treatment tended to decrease milk fat percentage $(P=0.07)$, however there was no treatment by day interaction. 


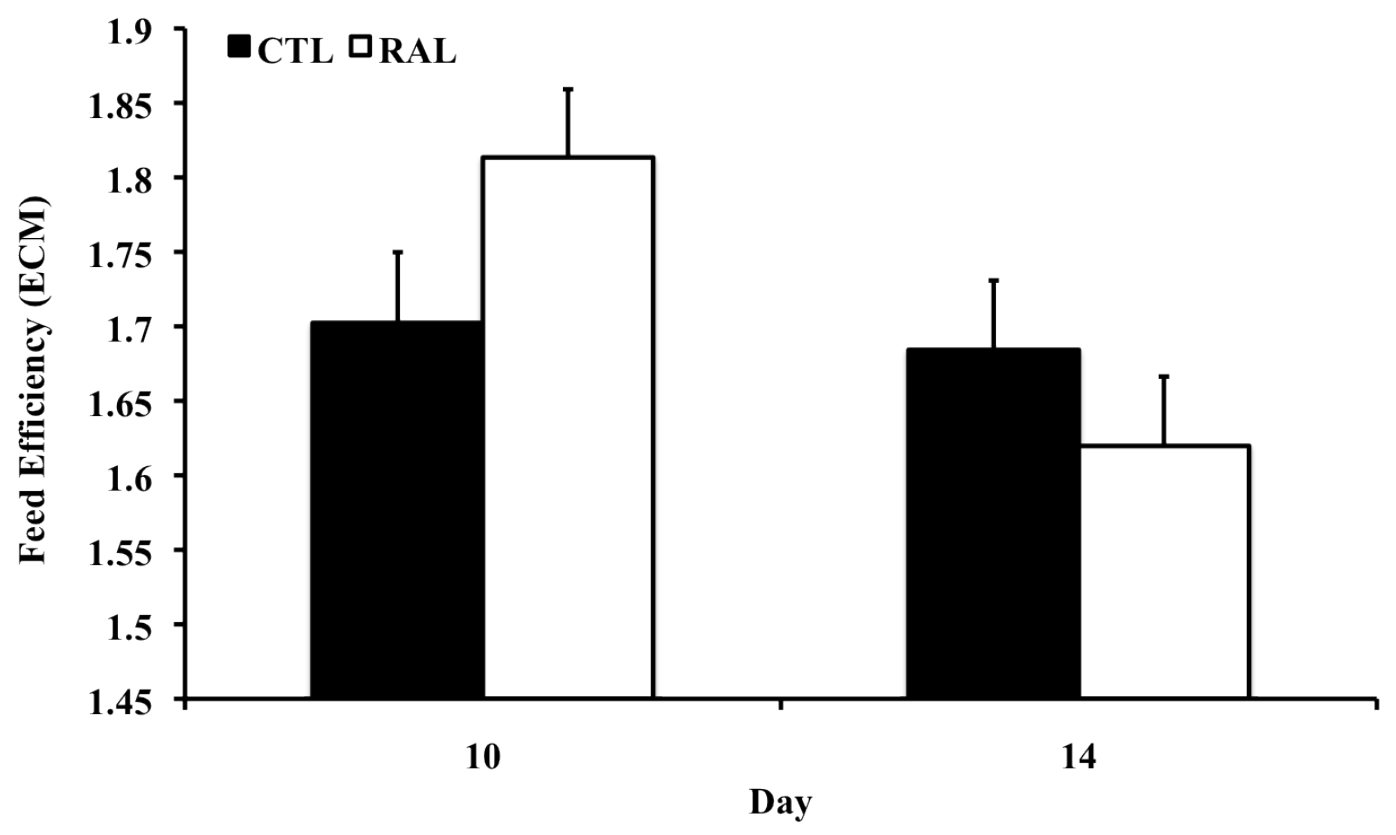

Figure 2.6: The effects of RAL treatment on energy-corrected milk (ECM) feed efficiency (FE) for CTL and RAL cows during P2. Treatments were $100 \mathrm{~g}$ daily (as fed) of either sucrose (CTL) or Rally ${ }^{\circledR}$ (RAL) mixed into the ration. P2 was the heat stress portion of the experiment beginning on day 7 and continuing until the last day of the trial (day 18). During P2 animals were were housed in environmental chambers and subjected to cyclical temperatures (designed to mimic ambient daily variation during the summer months) ranging from 23.8 to $30.2^{\circ} \mathrm{C}$, with the temperature humidity index ranging from 69.3 to 75.5 . Days marked with $\dagger$ designate significance at $\mathrm{P}<0.1$ Feed efficiency was calculated using the equation $\mathrm{FE} \mathrm{ECM}=(\mathrm{ECM} /$ dry matter intake $)$ on days 10 and 14 . There was a treatment by day interaction for ECM $(P=0.02)$, however there was no effect of treatment. 


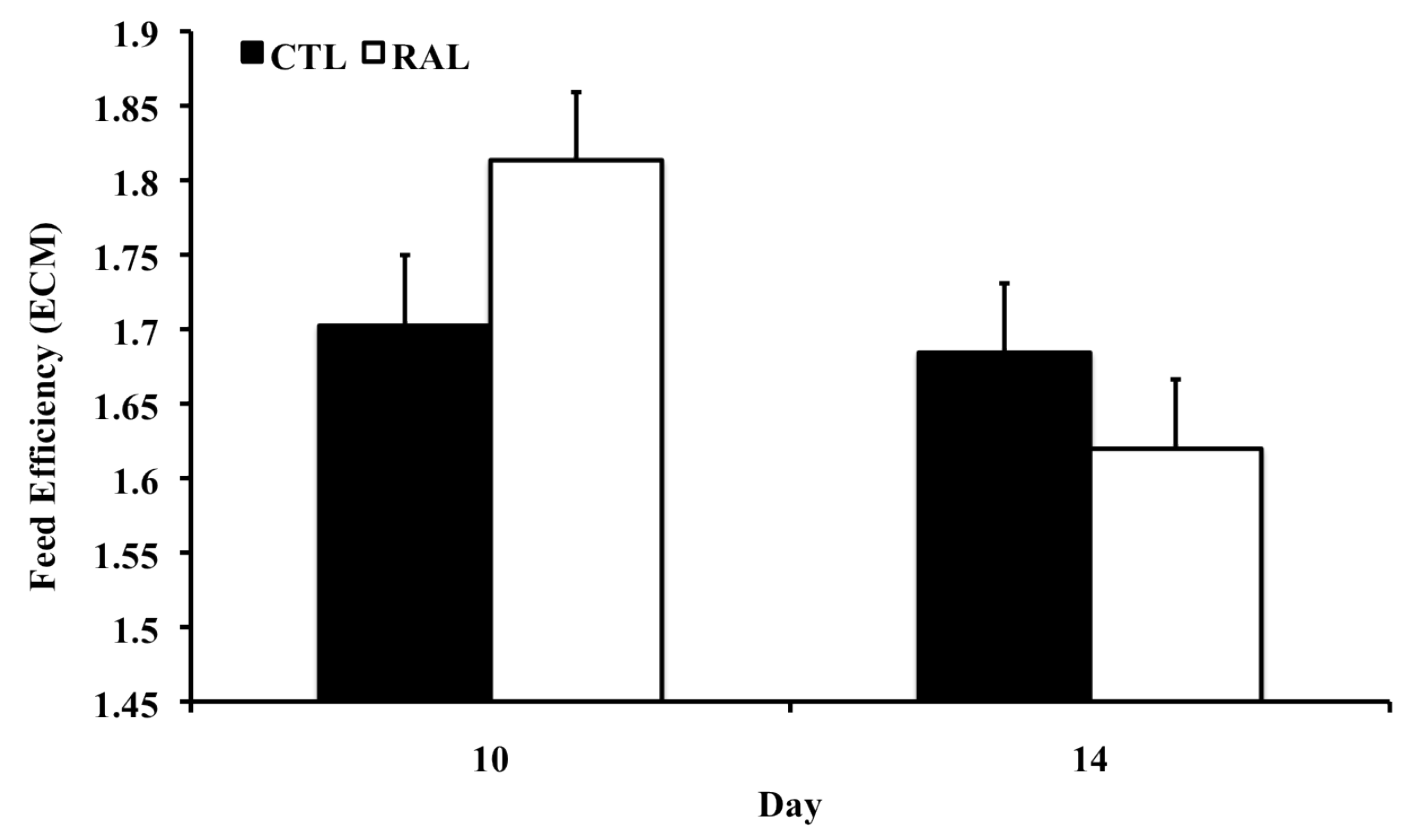

Figure 2.7: The effects of RAL treatment on 3.5\% fat-corrected milk (FCM) feed efficiency for CTL and RAL cows during P2. Treatments were $100 \mathrm{~g}$ daily (as fed) of either sucrose (CTL) or Rally ${ }^{\circledR}$ (RAL) mixed into the ration. P2 was the heat stress portion of the experiment beginning on day 7 and continuing until the last day of the trial (day 18). During P2 animals were were housed in environmental chambers and subjected to cyclical temperatures (designed to mimic ambient daily variation during the summer months) ranging from 23.8 to $30.2^{\circ} \mathrm{C}$, with the temperature humidity index ranging from 69.3 to 75.5 . Feed efficiency (3.5\% FCM) was calculated using the equation $\mathrm{FE} 3.5 \% \mathrm{FCM}=(3.5 \% \mathrm{FCM} /$ dry matter intake) on days 10 and 14 . There was a treatment by day interaction for $3.5 \%$ FCM $(P=0.02)$, however there was no effect of treatment. 


\section{REFERENCES}

Armstrong, D. V. 1994. Heat stress interaction with shade and cooling. J. Dairy Sci 77:2044-2050.

Baldwin, R. L., J. H. Thornley, and D. E. Beever. 1987. Metabolism of the lactating cow. II. Digestive elements of a mechanistic model. J. Dairy Res. 54.107.

Ballard, F. J. 1965. Glucose utilization in mammalian liver. Comp. Biochem. Physiol. 14:437-443.

Bandaranayaka, D. D., and Holmes, C. W. 1976. Changes in the composition of milk and rumen contents in cows exposed to a high ambient temperature with controlled feeding. Trop. Anim. Health Prod. 8:38-46.

Banos, G., M. P. Coffey, and S. Brotherstone. 2005. Modeling daily energy balance of dairy cows in the first three lactations. J. Dairy Sci. 88: 2226-2237.

Bauman, D. E., and W. B. Currie. 1980. Partitioning of nutrients during pregnancy and lactation: A review of mechanisms Involving homeostasis and homeorhesis. J. Dairy Sci 63:1514-1529.

Baumgard, L. H., Odens, L. J., Kay, J. K., Rhoads, R. P., VanBaale, M. J., and R.J. Collier. 2006. Does negative energy balance (NEBAL) limit milk synthesis in early lactation? Proc. Southwest Nutr. Conf. 181-187.

Baumgard, L. H., and R. P. Rhoads. 2007. The effects of hyperthermia on nutrient partitioning. Proc. Cornell Nutr. Conf. 93-104.

Beatty, D. T., A. Barnes, A., E. Taylor, D. Pethick, D., M. McCarthy, and S.K. Maloney. 2006. Physiological responses of Bos taurus and Bos indicus cattle to prolonged, continuous heat and humidity. J. Animal Sci. 84:972-985.

Beede, D., K. and R.J. Collier. 1986. Potential nutritional strategies for intensively managed cattle during thermal stress. J. Dairy. Sci. 62:543-554.

Beerda, B., W. Ouweltjes, L.B. Sebek, J.J. Windig, and R.F. Veerkamp. 2007.Effects of genotype by environment interactions on milk yield, energy balance, and protein balance. J. Dairy Sci 90:219-228.

Berman, A., 1968. Nychthemeral and seasonal patterns of thermoregulation in cattle. Aust. J. Agric. Res. 19:181-188. 
Berman, A., Y. Folman, M. Kaim, M. Mamen, Z. Herz, D. Wolfenson, A. Arieli, and Y. Graber. 1985. Upper critical temperatures and forced ventilation effects for high-yielding dairy cows in a subtropical climate. J. Dairy Sci. 68:1488-1495.

Berman, A. 2004. Tissue and external insulation estimates and their effects on prediction of energy requirements and of heat stress. J. Dairy Sci 87:1400-1412.

Biggers, B. G., R.D. Geisert, R.P. Wetteman, and D.S. Buchanan. 1987. Effect of heat stress on early embryonic development in the beef cow. J. Anim. Sci. 64:1512-1518.

Bohmanova, J., I. Misztal, and J.B. Cole. 2007. Temperature-humidity indices as indicators of milk production losses due to heat stress. J. Dairy Sci 90:1947-1956.

Bouraoui, R., M. Lahmar, A. Majdoub, M. Djemali, and R. Belyea. 2002. The relationship of temperature-humidity index with milk production of dairy cows in a Mediterranean climate. Anim. Res. 51:479-492.

Brockman, R. P. 1978. Roles of glucagon and insulin in the regulation of metabolism in ruminants. A review. Can. Vet. J. 19:5.

Calif. Dep. Food Agric. 2006. Hot topics affecting California Agriculture. An update from Sec.Kawamura. Sacramento: Calif. Dep. Food Agric. Accessed May 27, 2008. http://www.cdfa.ca.gov/exec/Public_Affairs/pdf/AGOnAg080306.pdf.

Collier, R. J., D. K. Beede, W. W. Thatcher, L. A. Israel, and C. J. Wilcox. 1982. Influences of environment and its modification on dairy animal health and production. J. of Dairy Sci. 65:2213-2227.

Dikmen, S., and and P. J. Hansen. 2009. Is the temperature-humidity index the best indicator of heat stress in lactating dairy cows in a subtropical environment? J. Dairy Sci. 92:109-116.

Dillon, P., D. P. Berry, R. D. Evans, F. Buckley, F., and Horan, B. 2006. Consequences of genetic selection for increased milk production in European seasonal pasture based systems of milk production. Livest. Sci. 99:141-158.

Drackley, J. K., T. R. Overton, and G. N. Douglas. 2001. Adaptations of glucose and long-chain fatty acid metabolism in liver of dairy cows during the periparturient period. J. Dairy Sci. 84(E Suppl.):E100-E112.

Drackley, J. K., T. M. Cicela, and D. W. LaCount. 2003. Responses of primiparous 
and multiparous Holstein cows to additional energy from fat or concentrate during summer. J. Dairy Sci 86:1306-1314.

Drovers Cattle Netw. 2011. Heat wave kills as many as 4,000 cattle last week in Iowa. http://www.cattlenetwork.com/cattle-resources/hot-topics/Heat-wavekills-as-many-as-4000-cattle-last-week-inIowa-126763608.html.

Finch, V. A., I. L. Bennett, and C. R. Holmes. 1982. Sweating response in cattle and its relation to rectal temperature, tolerance of sun and metabolic rate. J. Agric. Sci. 99:479-487.

Finch, V. A. 1985. Comparison of non-evaporative heat transfer in different cattle breeds. Aust. J. Agric. Res. 36:497-508.

Fox, D. G., and T. P. Tylutki. 1998. Accounting for the effects of environment on the nutrient requirements of dairy cattle. J. Dairy Sci. 81:3085-3089.

Hahn, G. L. 1999. Dynamic responses of cattle to thermal heat loads. J. Anim. Sci. $77: 10-20$.

Howden, S. M., and J. Turnpenny, J. 1997. Modeling heat stress and water loss of beef cattle in subtropical Queensland under current climates and climate change. In McDonald, D. A., and M. McAlleer (Eds), Modism 97. International Congress on Modeling and Simulation, Proceedings, 8-11 December, University of Tasmania, Hobart(pp. 1103-1108). Modeling and Simulation Society of Australia, Canberra, Australia.

Igono, M. O., G. Bjotvedt, and H. T. Sanford-Crane. 1992. Environmental profile and critical temperature effects on milk production of Holstein cows in desert climate. Int. J. Biometeorol. 36:77-87.

Ingraham, R. H., D. D. Gillette, and W.D. Wagner. 1974. Relationship of temperature and humidity to conception rate of Holstein cows in subtropical climate. J. Dairy Sci. 57:476-481.

Ingraham, R. H., R. W. Stanley, and W.C. Wagner. 1976. Relationship of temperature and humidity to conception rate of Holstein cows in Hawaii. J. Dairy Sci. 59:2086-2090.

Jesse, B. W., R. S. Emery, and J. W. Thomas. 1986. Control of bovine hepatic fatty acid oxidation. J. Dairy Sci. 69:2290-2297. 
Johnston, J. E., F. B. Hamblin, and G.T. Schrader. 1958. Factors concerned in the comparative heat tolerance of Jersey, Holstein and Red Sindhi-Holstein (F1) cattle. J. Anim. Sci. 17:473-479.

Jones, P. D., and A. Moberg. 2003. Hemispheric and large-scale surface air temperature variations: An extensive revision and an update to 2001. J. Clim. 16:206-223.

Jordan, E. R. 2003. Effects of Heat Stress on Reproduction. J. Dairy Sci. 86(E. Suppl. E):104-114.

Kadzere, C. T., M. R. Murphy, N. Silanikove, and E. Maltz. 2002. Heat stress in lactating dairy cows: a review. Livestock Prod. Sci. 77:59-91.

Kibler, H. H., and S. Brody. 1950. Environmental physiology with special reference to domestic animals. XI. Effects of temperature, $50^{\circ} \mathrm{F}$ to $105^{\circ} \mathrm{F}$. and $50^{\circ} \mathrm{F}$ to $9^{\circ}$ F. on heat production and cardiorespiratory activities in Brahman, Jersey and Holstein cows. Mo. Agr. Exp. Sta. Res. Bul. 464.

Koo, S. H., A. K. Dutcher, and H. C. Towle. 2001. Glucose and insulin function through two distinct transcription factors to stimulate expression of lipogenic enzyme genes in liver. J. Biol. Chem. 276: 9437-9445.

Kunz, P. L., J. W. Blum, and I. C. Hart. 1985. Effects of different energy intakes before and after calving on food intake, performance and blood hormones and metabolites in dairy cows. Anim. Prod. 40:219.

LeBlanc, S. 2010. Monitoring metabolic health of dairy cattle in the transition period. J. Reprod. Dev. 56(Suppl.):S29-S35.

Lemerle, C., and M. E. Goddard. 1986. Assessment of heat stress in dairy cattle in Papua New Guinea. Trop. Anim. Health Prod. 18:232-242.

Littell, R. C., P. R. Henry, and C. B. Ammerman. 1998. Statistical analysis of repeated measures data using SAS procedures. J. Anim. Sci. 76:1216-1231.

McDowell, R. E., E. G. Moody, P. J. Van Soest, R. P. Lehmann, and G. L. Ford. 1969. Effect of heat stress on energy and water utilization of lactating cows. J. Dairy Sci. 52:188-194.

McDowell, R. E., J. C. Wilk, and C. W. Talbott. 1996. Economic Viability of Crosses of Bos taurus and Bos indicus for Dairying in Warm Climates. J. Dairy 
Sci. 79:1292-1303.

Moallem, U., G. Altmark, H. Lehrer, and A. Arieli. 2010. Performance of high-yielding dairy cows supplemented with fat or concentrate under hot and humid climates. J. Dairy Sci. 93:3192-3202.

Moore, C. E., J. K. Kay, M. J. VanBaale, R. J. Collier, and L. H. Baumgard. 2005. Effect of supplemental conjugated linoleic acids on heat-stressed Brown Swiss and Holstein cows. J. Dairy Sci.Sci 88:1732-1740.

Morrissey, P. A. 1985. Lactose: Chemical and physicochemical properties. Pages 1-34 in Development in Dairy Chemistry (Fox, P.F., ed), Vol 3, pp. 1-34. Elsevier Science Publishers, London and New-York.

Muller, C.J.C., Botha, J.A., Smith, W.W., 1994a. Effect of shade on various parameters of Friesian cows in a Mediterranean climate in South Africa. 1. Feed and water intake, milk production and milk composition. South Afric. J. Anim. Sci. 24:49-55.

Muller, C.J.C., Botha, J.A., Coetzer, W.A., Smith, W.W., 1994b. Effect of shade on various parameters of Friesian cows in a Mediterranean climate in South Africa. 2. Physiological responses. South Afric. J. Anim. Sci. 24:56-60.

NRC. 2001. Nutrient Requirements of Dairy Cattle. 7th ed. Natl. Acad. Press, Washington, DC.

Ominski K. H., A. D. Kennedy, K. M. Wittenberg, and S. A. Moshtaghi Nia. 2002. Physiological and production responses to feeding schedule in lactating dairy cows exposed to short-term, moderate heat stress. J. Dairy Sci. 85:730-737.

Oseni, S., I. Misztal, S. Tsuruta, and R. Rekaya. 2004. Genetic components of days open under heat stress. J. Dairy Sci. 87:3022-3028.

Ospina, P. A., D. V. Nydam, T. Stokol, and T. R. Overton. 2010. Associations of elevated nonesterified fatty acids and $\beta$-hydroxybutyrate concentrations with early lactation reproductive performance and milk production in transition dairy cattle in the northeastern United States. J. Dairy Sci. 93:1596-1603.

Overton, T. R., and M. R. Waldron. 2004. Nutritional management of transition dairy cows: strategies to optimize metabolic health. J. Dairy Sci. 87(E Suppl.):E105-E119. 
Peaker, M. 1977. Mechanism of milk secretion: milk composition in relation to potential difference across the mammary epithelium. J. Physiol. 270:489-505.

Ravagnolo, O., and I. Misztal. 2000. Genetic component of heat stress in dairy cattle, parameter estimation. J. Dairy Sci. 83:2126-2130.

Ravagnolo, O., and I. Misztal. 2002. Effect of heat stress on nonreturn rate in Holsteins: fixed-model analyses. J. Dairy Sci. 85:3101-3106.

Ray, D. E., T. J. Halbach, and D. V. Armstrong. 1992. Season and lactation number effects on milk production and reproduction of dairy cattle in Arizona. J. Dairy Sci. 75:2976-2983.

Reynolds, C. K. 2006. Production and metabolic effects of site of starch digestion in dairy cattle. Anim. Feed Sci. Technol. 130:78-94.

Rhoads, M. L., R. P. Rhoads, M. J. VanBaale, R. J. Collier, S. R. Sanders, W. J. Weber, B. A. Crooker, and L. H. Baumgard. 2009. Effects of heat stress and plane of nutrition on lactating Holstein cows: I. Production, metabolism, and aspects of circulating somatotropin. J. Dairy Sci. 92:1986-1997.

Rhoads, M. L., J. W. Kim, R. J. Collier, B. A. Crooker, Y. R. Boisclair, L. H. Baumgard, and R. P. Rhoads. 2010. Effects of heat stress and nutrition on lactating Holstein cows: II. Aspects of hepatic growth hormone responsiveness. J. Dairy Sci. 93:170-179.

Sanchez, J. P., I. Misztal, I. Aguilar, B. Zumbach, and R. Rekaya. 2009. Genetic determination of the onset of heat stress on daily milk production in the US Holstein cattle. J. Dairy Sci 92:4035-4045.

Scott, I. M., H. D. Johnson, and G. L. Hahn. 1983. Effect of programmed diurnal temperature cycles on plasma thyroxine level, body temperature, and feed intake of Holstein dairy cows. Int. J. Biometeor. 27:47-62.

Shwartz, G., M. L. Rhoads, M. J. VanBaale, R. P. Rhoads, and L. H. Baumgard. 2009. Effects of a supplemental yeast culture on heat- stressed lactating Holstein cows. J. Dairy Sci. 92:935-942.

Stangassinger, M., and D. Giesecke. 1986. Splanchnic metabolism of glucose and related energy substrates. Proceedings of 6th International Symposium on Ruminant Physiology. Banff (Canada). 10-14. 
Stott, G. H., and R. J. Williams. 1962. Causes of low breeding efficiency in dairy cattle associated with seasonal high temperatures. J. Dairy Sci 45:1369-1375.

St. Pierre, N., B. Cobanonov, and G. Schnitkey. 2003. Economic losses from heat stress by U.S. livestock industries. J. Dairy Sci. 86(E. Suppl.):E52-E77.

Tao, S., J. W. Bubolz, B. C. do Amaral, I. M. Thompson, M. J. Hayen, S. E. Johnson, and G. E. Dahl. 2011. Effect of heat stress during the dry period on mammary gland development. J. Dairy Sci. 94:5976-5986.

Thompson, W. R., J. C. Meiske, R. D. Goodrich, J. R. Rust, and F. M. Byers. 1983. Infuence of body composition on energy requirements of beef cows during winter. J. Anim. Sci. 56:1241-1252.

Van Arendonk, J. A. M., G. J. Nieuwhof, H. Vos, and S. Korver. 1991. Genetic aspects of feed intake and efficiency in lactating dairy heifers. Livest. Prod. Sci. $29: 263-275$.

Vitali, A., M. Segnalini, L. Bertocchi, U. Bernabucci, A. Nardone, and N. Lacetera. 2009. Seasonal pattern of mortality and relationships between mortality and temperature-humidity index in dairy cows. J. Dairy Sci. 92:3781-3790.

West, J. W., B. G. Mullinix, and J. K. Bernard. 2003. Effects of hot, humid weather on milk temperature, dry matter intake, and milk yield of lactating dairy cows. J. Dairy Sci. 86:232-242.

West, J. W. 2003. Effects of heat-stress on production in dairy cattle. J. Dairy Sci. 86: $2131-2144$.

Wheelock, J. B., R. P. Rhoads, M. J. VanBaale, S. R. Sanders, and L. H. Baumgard. 2010. Effects of heat stress on energetic metabolism in lactating Holstein cows. J. Dairy Sci. 93:644-655.

Zimbelman, R. B., L. H. Baumgard, and R. J. Collier. 2010. Effects of encapsulated niacin on evaporative heat loss and body temperature in moderately heat-stressed lactating Holstein cows. J. Dairy Sci. 93:2387-2394. 


\section{Appendix A}

\section{Supplementary Information for Chapter 2}

\section{A.1 Interpretive Summary}

\section{Effects of a commercial feed additive on production losses during acute}

heat stress conditions in Holstein dairy cows

Davison

Heat stress occurs when the environmental temperature exceeds the cow's thermal comfort zone, necessitating the employment of energetically costly cooling mechanisms such as sweating and panting. Heat stressed dairy cattle experience reduced milk production and quality, decreased dry matter intake, and increased incidence of health problems resulting in lost revenue approximating $\$ 1$ billion annually. The ability of the commercial feed additive Rally ${ }^{\circledR}$ to mitigate production losses during heat stress was investigated in this experiment. Rally ${ }^{\circledR}$ supplementation increased dry matter intake and milk yield and decreased milk fat percent and the plasma nonesterified fatty acid concentration. This indicates that Rally ${ }^{\circledR}$ supplementation has the ability to not 
only improve milk production during heat stress, but also to promote a more favorable energy balance in mid-lactation dairy cows.

\section{A.2 Running Head}

\section{FEED ADDITIVE ON HEAT STRESS}

Effects of a commercial feed additive on production losses during acute heat stress conditions in Holstein dairy cows. K. A. Davison*, R. Rodrigues*, J. A. Davidson ${ }^{\dagger}$, N. M. Barkley*, A. L. Kenny*, and M.

R. Waldron*1

*Division of Animal Sciences, University of Missouri-Columbia, MO 65211

† Land O’Lakes Purina Feed, Grey Summit, MO 63039

${ }^{1}$ Corresponding author: mrwaldron@bugnet.net 